\title{
Application of ecologically balanced technologies of rice cultivation in the Krasnodar Territory
}

\author{
Igor Prikhodko ${ }^{1 *}$, Stanislav Vladimirov ${ }^{1}$, and Daniel Alexandrov ${ }^{1}$ \\ ${ }^{1}$ Kuban State Agrarian University named after I.T. Trubilin, st. Kalinina, 13, Krasnodar, 350044, \\ Russia
}

\begin{abstract}
The domestic and foreign research in the field of rice cultivation carried out over the past 10-15 years has identified four main promising technologies that can reduce the cost of rice produced: 1 intermittent flooding; 2 - periodic moistening without creating a layer of water; 3 - sprinkling, including surface irrigation; 4 - drip irrigation. Drip irrigation of rice is the most priority area of research, since it can significantly reduce the irrigation rate, labor costs, the cost of rice production and anthropogenic load. The purpose of our research was to develop a new technology of rice cultivation with drip irrigation adapted for the climatic and soil conditions of the Krasnodar Territory. As a result of the research carried out, a drip irrigation technological scheme was developed and implemented for LLC "Chernoerkovskoye" of the Slavyansky District of the Krasnodar Territory. The developed scheme of rice cultivation on drip irrigation has proven its effectiveness, which was expressed in improving the reclamation state of soils, increasing the profitability of production by $22 \%$ and increasing the yield by $20 \%$, reducing the irrigation rate by an average of 5.3 times, the cost of rice grain by $15 \%$ and labor intensity by $34 \%$.
\end{abstract}

\section{Introduction}

It is known from the world practice of rice production [1-6] that rice is a moisture-loving crop that requires large volumes of irrigation water and labor costs for its production. Therefore, scientific research to find new solutions to reduce the cost of rice production has always been relevant, including in the historical aspect of rice cultivation [7-9]. However, in the last decade, due to the stable positive dynamics of demographic growth of the population, a decrease in irrigation water volumes and, in connection with this, the limited irrigation fund of land, as well as an increase in prices for all components of rice production: seed material, fertilizers, fuel and lubricants, payment for water supply to rice irrigation systems [10-13], the problem of the transition of rice producers to less costly cultivation technologies has reached its apogee, and ways to solve it have become a priority at the state level.

In connection with the above, the purpose of our research is to develop new

\footnotetext{
*Corresponding author :prihodkoigor2012@yandex.ru
} 
technological solutions for the cultivation of rice with a significant reduction in direct costs of its production.

The modern level of scientific and technological progress allows minimizing the use of resources to obtain consistently high yields of high-quality rice grain without prejudice to the reclamation state of soils and the ecosystem of the region [14]. The most promising technology is the cultivation of rice using drip irrigation. This is confirmed by more than ten years of successful experience in the cultivation of rice with drip irrigation in China [15], as well as domestic developments of technologies for cultivation of rice with drip irrigation, which have been successfully tested in the farms of the Volgograd and Rostov regions [16-19], and have proven the effectiveness and feasibility further research in this direction. The effectiveness of drip irrigation is due to a number of factors [20]: a reduction in the irrigation rate, the possibility of rice cultivation on the lands of non-irrigation fund, the development of fundamentally new rice crop rotations with the inclusion of melons and vegetables in them. It should be noted that the areas of the irrigation fund of the Krasnodar Territory available for planting rice annually decrease as a result of partial and sometimes complete non-compliance with crop rotations and rice cultivation technologies, which leads to a decrease in soil fertility up to partial and / or complete withdrawal of lands from agricultural purposes [21]. In such cases, the rice irrigation systems require major repairs that are not economically viable. All of the above confirms the relevance of our research, and the research results can be used to develop mathematical models that help workers in the agro-industrial complex make timely management decisions to develop optimally adapted flow charts for rice production using drip irrigation in order to obtain guaranteed high yields of rice without reducing reclamation state of soils.

\section{Materials and methods}

Tests of the method of rice cultivation were carried out in the Krasnodar Territory at LLC "Chernoerkovskoe" of the Slavyansky District (2nd department) on a rice check (hereinafter "experimental field") with an area of 4.5 hectares each.

The farm uses a diagram of an engineering rice plot of the Krasnodar type.

The cultivated rice crop was the Rapan variety.

The predecessor in the first year of the implementation of the method is rice.

On the experimental field from 2016 to 2019 , the following crop rotation was applied:

- 2016: rice (seedling) + tomato (seedling);

- 2017: rice (seedling) + peas (seminal);

- 2018: rice (seedling) + sweet pepper (seedling);

- 2019: rice (seedling) + lupine (seminal).

The method of cultivating rice on the checks of the rice irrigation system with drip irrigation under polyethylene and/or biodegradable mulching perforated film included a list of technological operations presented in Table 1.

Table 1. The list of technological operations for the cultivation of rice on drip irrigation under perforated plastic and / or mulch film.

\begin{tabular}{|c|c|c|c|}
\hline \multirow[b]{2}{*}{ № } & \multirow[b]{2}{*}{ Name of technological operations } & \multicolumn{2}{|c|}{ Unit composition } \\
\hline & & tractor & $\begin{array}{l}\text { agricultural } \\
\text { machine }\end{array}$ \\
\hline 1 & 2 & 3 & 4 \\
\hline \multicolumn{4}{|c|}{ Autumn 2015 (first year of implementation of the method) } \\
\hline 1 & $\begin{array}{c}\text { Cutting and restoration of peripheral grooves (depth 0.4-0.6 } \\
\mathrm{m} \text {, along the perimeter of the check) }\end{array}$ & DT-75B & MK-23 \\
\hline 2 & Aligning checks & DT-75B & D-569 \\
\hline 3 & Basic tillage (depth $0.22-0.25 \mathrm{~m}$ ) & $\begin{array}{c}\mathrm{T}-150 \\
(\mathrm{DT}-75 \mathrm{~B})\end{array}$ & $\begin{array}{l}\text { PLN-5-35 } \\
(\mathrm{PCN}-3,2)\end{array}$ \\
\hline
\end{tabular}




\begin{tabular}{|c|c|c|c|}
\hline 4 & Cleaning of irrigation and waste canals & EO-2621 & - \\
\hline 5 & Backfilling of check rollers up to design marks & DT-75B & D-569 \\
\hline 6 & Deep loosening (chiseling, depth 0.16-0.18 m) & DT-75B & KZU-0,3V \\
\hline 7 & Loading organic fertilizer into an organic fertilizer spreader & JCB 3CX & - \\
\hline 8 & Organic fertilization & MTZ-1221 & ROUM-14 \\
\hline 7 & $\begin{array}{l}\text { Disking with incorporation of organic fertilizers (depth } \\
0.10-0.12 \mathrm{~m} \text { ) and application rate of } 50 \mathrm{t} / \mathrm{ha} \\
\end{array}$ & DT-75B & BDT $-3,0$ \\
\hline \multicolumn{4}{|c|}{ Spring-Autumn 2016 (first year of implementation of the method) } \\
\hline 9 & $\begin{array}{l}\text { Harrowing with tooth harrows in two tracks to a depth of } \\
0.08 \mathrm{~m}\end{array}$ & DT-75B & MVTZ-1,2 \\
\hline 10 & $\begin{array}{l}\text { Formation of technological driveways and passages to a } \\
\text { depth of } 0.2 \mathrm{~m}\end{array}$ & DT-75B & MK-17 \\
\hline 11 & Delivery of non-woven geosynthetic material & MTZ-1221 & 2 PTS-4 \\
\hline 12 & $\begin{array}{l}\text { Coating with nonwoven geosynthetic material of } \\
\text { technological passages and driveways }\end{array}$ & \multicolumn{2}{|c|}{ Manually } \\
\hline 13 & $\begin{array}{c}\text { Delivery of drip irrigation and fertigation system elements } \\
\text { (pumps, filters for fine and coarse water purification, water } \\
\text { meter, liflet hose, drip tape, taps, valves, tees, splitters, } \\
\text { plugs, injector, fertilizer tank, etc.) }\end{array}$ & MTZ-1221 & 2 PTS -4 \\
\hline 14 & $\begin{array}{c}\text { Drip irrigation system assembly including fertigation } \\
\text { system (no drip tape laying) }\end{array}$ & \multicolumn{2}{|c|}{ Manually } \\
\hline 15 & $\begin{array}{l}\text { Laying of Netafim drip tapes, water consumption of each } \\
\text { dropper } 1.8 \mathrm{l} / \mathrm{h} \text {, diameter and wall thickness of the drip tape } \\
-16 \mathrm{~mm} \text { and } 0.2 \mathrm{~mm} \text {, respectively, distance between } \\
\text { droppers } 0.2 \mathrm{~m} \text {, distance between drip lines }-0.24 \mathrm{~m}\end{array}$ & MTZ-1221 & $\begin{array}{l}\text { Drip irrigation tube } \\
\text { unwinder tm } \\
\text { "GreenBull" }\end{array}$ \\
\hline 16 & $\begin{array}{l}\text { Single pre-sowing treatment of seeds with a growth } \\
\text { regulator "Albit" at a dose of } 50-100 \mathrm{ml} / \mathrm{t}\end{array}$ & \multicolumn{2}{|c|}{ Manually } \\
\hline 17 & $\begin{array}{l}\text { Planting rice seedlings (Rapan variety) in nutrient pots in a } \\
\text { phytotron, a mixture of various components is used as a } \\
\text { substrate: highly fertile field land, sod land, humus, high } \\
\text { peat, coarse sand with the addition of microelements to the } \\
\text { substrate before planting rice seeds with a norm of } \\
\text { N80P120K60 in kg a.d./ha, the humus content in the } \\
\text { substrate is not less than } 40 \% \text {, the substrate density is less } \\
\text { than one, the porosity is } 60-90 \% \text {, the air content is not less } \\
\text { than } 10 \% \text {. Maintaining the temperature regime: in the } \\
\text { daytime } 20-24^{\circ} \mathrm{C} \text {, in cloudy weather - } 16-18^{\circ} \mathrm{C} \text {, at night - } \\
15-16^{\circ} \mathrm{C} \text {, optimal pre-irrigation humidity - at the level of } \\
55-65 \% \text { of HB, relative humidity - } 60-70 \% \text {. To maintain a } \\
\text { stable regime when these parameters were increased, } \\
\text { ventilation was switched on. During the period of seedling } \\
\text { growing, the lighting was controlled using fluorescent } \\
\text { lamps and turned off at night. Seedlings in the phase of } 2-3 \\
\text { leaves were fed with nitrogen fertilizers in dissolved form } \\
\text { at the rate of N40 in kg a.d./ha. Before planting in the } \\
\text { ground, the seedlings corresponded to the standard, had } 6-7 \\
\text { leaves with a green color, with a well-developed root } \\
\text { system and not infected with pests and diseases. }\end{array}$ & \multicolumn{2}{|c|}{ Manually } \\
\hline 18 & $\begin{array}{c}\text { Pre-planting irrigation with an irrigation rate providing soil } \\
\text { moisture of } 90 \% \text { of } \mathrm{HB} \text { in a layer of } 0.6 \mathrm{~m}\end{array}$ & \multicolumn{2}{|c|}{ Drip irrigation system } \\
\hline 19 & $\begin{array}{c}\text { Spraying the soil surface with soil herbicides: "Ordram" } \\
720 \text { EC }(5.01 / \text { ha, treatment rate } 1)+\text { Gezagard with a rate } \\
\text { of } 60-80 \mathrm{ml} / 101 \text { of water to combat annual dicotyledonous } \\
\text { and cereal weeds }\end{array}$ & $\begin{array}{l}\text { Self-propelled sprayer } \\
\text { IBIS-2500-18P }\end{array}$ & \\
\hline 20 & Shelter of ridges with perforated polyethylene mulch film & MTZ-1221 & Film stacker \\
\hline 21 & $\begin{array}{c}\text { Spraying BAS "Epin Extra" in the norm of 5-6 drops per } \\
0.51 \text { of water two days before planting seedlings to increase } \\
\text { survival rate and increase stress resistance }\end{array}$ & $\begin{array}{l}\text { Cordless sprayer } \\
\text { Clever } \\
\text { OE-12.5L-N }\end{array}$ & \\
\hline 22 & Planting rice seedlings & MTZ-1221 & $\begin{array}{l}\text { Transplanter } \\
\text { FTM } 2\end{array}$ \\
\hline
\end{tabular}




\begin{tabular}{|c|c|c|c|}
\hline 23 & $\begin{array}{c}\text { Drip irrigation of rice through a drip irrigation system } \\
\text { during the growing season of rice with the frequency and } \\
\text { rate of irrigation depending on compliance with the } \\
\text { condition for ensuring constant soil moisture } 80 \% \text { of HB in } \\
\text { a layer of } 0.4 \mathrm{~m}\end{array}$ & \multicolumn{2}{|c|}{ Drip irrigation system } \\
\hline 24 & $\begin{array}{l}\text { The introduction of microelements after complete survival } \\
\text { of rice seedlings (in the phase of } 8-9 \text { leaves) by fertigation } \\
\text { through a drip irrigation system by the norm } \mathrm{N}_{30} \mathrm{P}_{30} \mathrm{~K}_{30} \text { at } \\
\text { kg a.d./ha }\end{array}$ & \multicolumn{2}{|c|}{ Drip irrigation system } \\
\hline 25 & $\begin{array}{c}\text { Treatment with herbicides Bazagran, v.r., (bentazone, } 480 \\
\text { g/l), "BASF AG" of rice crops in the tillering phase, with a } \\
\text { consumption rate of } 2.0-4.01 / \text { ha and a working fluid } \\
\text { consumption of } 200-3001 / \text { ha }\end{array}$ & $\begin{array}{l}\text { Self-propelled sprayer } \\
\text { IBIS-2500-18P }\end{array}$ & - \\
\hline 26 & $\begin{array}{c}\text { Spraying of seedlings of young seedlings of BAS "Albid" at } \\
\text { the end of tillering before the start of emergence into the } \\
\text { tube at a dose of } 30 \mathrm{mg} / \text { ha to prevent lodging }\end{array}$ & $\begin{array}{l}\text { Self-propelled sprayer } \\
\text { IBIS-2500-18P }\end{array}$ & - \\
\hline 27 & $\begin{array}{l}\text { Introduction of microelements into the tillering phase of } \\
\text { rice by the method of fertigation through a drip irrigation } \\
\text { system with the norm } \mathrm{N}_{30} \mathrm{~kg} \text { a.d./ha }\end{array}$ & \multicolumn{2}{|c|}{ Drip irrigation system } \\
\hline 28 & \begin{tabular}{|}
$\begin{array}{c}\text { Treatment with fungicides in the phase of entering the tube } \\
\text { for prophylaxis (blast, fusarium, septoria), Kolosal, EC } \\
(250 \mathrm{~g} / \mathrm{l}) \text { rate } 0.751 / \mathrm{ha}\end{array}$ \\
\end{tabular} & $\begin{array}{l}\text { Self-propelled sprayer } \\
\text { IBIS-2500-18P }\end{array}$ & - \\
\hline 29 & Rice harvesting & $\begin{array}{l}\text { Harvester } \\
\text { Don } 1500 \\
\end{array}$ & - \\
\hline 30 & Transfer of rice seeds & $\begin{array}{l}\text { Kamaz grain carrier } \\
6360 \\
\end{array}$ & - \\
\hline 31 & $\begin{array}{c}\text { Presowing soaking of tomato seeds in Fitosporin-M } \\
\text { universal (paste) for } 1-2 \text { hours at a rate of } 1 \text { drop per } 100 \mathrm{~g}\end{array}$ & \multicolumn{2}{|c|}{ Manually } \\
\hline 32 & $\begin{array}{c}\text { Planting tomato seeds (variety Zagadka) } 55-60 \text { days before } \\
\text { planting in open ground, planting is carried out in } \\
\text { containers with a depth of } 8-10 \mathrm{~cm} \text { filled with soil } \\
\text { consisting of fine-grained sand, peat and humus with soddy } \\
\text { soil in a ratio of } 1: 1: 1: 1 \text {, respectively, after which grooves } \\
2-3 \mathrm{~cm} \text { deep are made at a distance of } 4 \mathrm{~cm} \text { each, into } \\
\text { which the seeds are laid out and sprinkled with a thin layer } \\
\text { of earth with light compaction and watering, then the } \\
\text { containers are covered with transparent polyethylene, while } \\
\text { the following air temperature regime is maintained in the } \\
\text { room: the first seven days after the emergence of seedlings } \\
\text { during the day } 17^{\circ} \mathrm{C}\left( \pm 2^{\circ} \mathrm{C}\right) \text { at night } 14^{\circ} \mathrm{C}\left( \pm 2^{\circ} \mathrm{C}\right) \text {, then } \\
\text { to the phase of } 2-3 \text { true leaves during the day } 22^{\circ} \mathrm{C}\left( \pm 2^{\circ}\right. \\
\left.\mathrm{C}) \text { at night } 18 \mathrm{C} \text { ( } \pm 2^{\circ} \mathrm{C}\right) \text {, soil temperature day and night } \\
\text { and } 150 \mathrm{C}( \pm 2 \mathrm{C}) \text { in the first week after germination, } \\
\text { while when the first sprouts appear, the film is removed } \\
\text { from the containers, at the same time, during the cultivation } \\
\text { of seedlings, two fertilizing with mineral fertilizers } \\
\text { "Intermag vegetable garden" are performed: the first at the } \\
\text { phase of the } 2 \text { nd present sheet, the second at the phase of } \\
\text { the } 3 \text { rd present sheet with the norm of } 1 \text { tbsp. spoon for } 3 \\
\text { liters of water, at the same time, during the cultivation of } \\
\text { seedlings, two fertilizing with mineral fertilizers "Intermag } \\
\text { vegetable garden" are performed: the first at the phase of } \\
\text { the } 2 \text { nd true leaf, the second at the phase of the } 3 \text { rd true leaf } \\
\text { with a rate of } 1 \text { tbsp. spoon for } 3 \text { liters of water, while } \\
\text { throughout the cultivation of seedlings, soil moisture is } \\
\text { maintained within } 70-75 \% \text { of the PPV, the recommended } \\
\text { water temperature is } 20^{\circ} \mathrm{C}\left( \pm 2^{\circ} \mathrm{C}\right) \text {. }\end{array}$ & Manua & \\
\hline
\end{tabular}




\begin{tabular}{|c|c|c|c|}
\hline 33 & \begin{tabular}{|} 
After the appearance of $2-3$ true leaves, tomato seedlings \\
are picketed into peat cups, while it is necessary to maintain \\
a distance between seedlings of at least $15 \mathrm{~cm}$ from each \\
other, while the following temperature regime is maintained \\
in the room: during the first three days after the emergence \\
of seedlings in the daytime $210 \mathrm{C}\left( \pm 1^{\circ} \mathrm{C}\right)$ at night $17^{\circ} \mathrm{C}$ \\
$\left( \pm 1^{\circ} \mathrm{C}\right)$, then in the daytime $19^{\circ} \mathrm{C}\left( \pm 1^{\circ} \mathrm{C}\right)$ at night $15^{\circ} \mathrm{C}$ \\
$\left( \pm 1^{\circ} \mathrm{C}\right)$, at the same time, during the cultivation of \\
seedlings, three additional fertilizing with mineral fertilizers \\
"Intermag Ogorod" is carried out: the first after 12 days \\
after picking the norm of 2 tbsp. tablespoons per 10 liters of \\
water, the second $10-12$ days after the first feeding with the \\
rate of 1 tbsp. spoon for 10 liters of water, the third 10 days \\
before planting in the ground while throughout the \\
cultivation of seedlings, soil moisture is maintained within \\
$65-70 \%$ of the PPV.
\end{tabular} & \multicolumn{2}{|c|}{ Manually } \\
\hline 34 & $\begin{array}{l}\text { Cutting 2-3 lower true leaves } 2-3 \text { days before planting } \\
\text { tomato seedlings, to improve the development of the first } \\
\text { flower cluster and reduce the likelihood of diseases, while } \\
\text { the leaf cut is made so that stumps remain } 1.5-2.0 \mathrm{~cm} \text { long } \\
\text { and disappear by themselves after drying }\end{array}$ & \multicolumn{2}{|l|}{-} \\
\hline 35 & \begin{tabular}{|c|} 
Pre-planting irrigation with the introduction of mineral \\
fertilizers by fertigation through a drip irrigation system \\
with a rate of $0.5 \mathrm{~kg}$ of potassium sulfate with \\
superphosphate and $250-300 \mathrm{~g}$ of ammonium nitrate per \\
area of $10 \mathrm{~m}^{2}$ with an irrigation rate providing soil moisture \\
of $90 \%$ of HB in a layer of $0.4 \mathrm{~m}$
\end{tabular} & \multicolumn{2}{|c|}{ Drip irrigation system } \\
\hline 36 & $\begin{array}{c}\text { Planting seedlings in open ground (before planting in open } \\
\text { ground, the seedling bush should be at least } 20 \mathrm{~cm} \text { high, } \\
\text { have } 10( \pm 2) \text { well-developed leaves and one or two } \\
\text { inflorescences, while the rice stubble is removed and a peat } \\
\text { pot is placed in the formed hole with seedlings with powder } \\
\text { to the first fox and light compaction of the soil, while a peg } \\
40-50 \mathrm{~cm} \text { high is placed near each tomato plant, to which } \\
\text { the tomato seedlings are tied }\end{array}$ & MTZ-1221 & $\begin{array}{l}\text { Platform for } \\
\text { harvesting and } \\
\text { planting seedlings } \\
\text { of vegetables } \\
\text { PUO-1A }\end{array}$ \\
\hline 37 & $\begin{array}{c}\text { Drip irrigation of tomatoes through a drip irrigation system } \\
\text { during the growing season with the frequency and rate of } \\
\text { irrigation, depending on compliance with the condition for } \\
\text { ensuring constant moisture in the soil layer of } 1 \mathrm{~m}: 65-70 \% \\
\text { of the PPV from planting to the beginning of flowering, } 75- \\
80 \% \text { of the PPV in the flowering phase, } 80-85 \% \text { of PPV in } \\
\text { the fruiting phase } \\
\text { the }\end{array}$ & \multicolumn{2}{|c|}{ Drip irrigation system } \\
\hline 38 & \begin{tabular}{|c|} 
3-4 times spraying tomato plants with the fungicide \\
"Ridomilgold" in the form of a working solution of \\
standard concentration $(0.5 \%)-5$ g per 11 of water with an \\
interval of $1-2$ weeks, regardless of the causative agent and \\
the affected crop during the growing season to combat with \\
fungal diseases from the consumption rate of working fluid \\
1 liter per $20 \mathrm{~m} 2$ to combat fungal diseases, while the \\
waiting period from the last treatment to harvesting the \\
fruits is 14 days
\end{tabular} & $\begin{array}{l}\text { Self-propelled sprayer } \\
\text { IBIS-2500-18P }\end{array}$ & - \\
\hline 39 & \begin{tabular}{|c|} 
Spraying of crops in the phase of $2-4$ leaves in weeds, \\
regardless of the phase of development of the tomato \\
culture with pesticides Panther, EC $(40 \mathrm{~g} / 1)$ or Bagheera, \\
EC ( $40 \mathrm{~g} / \mathrm{l})$ with a rate of $0.75-1.01(\mathrm{~kg}) /$ ha for the control \\
of annual cereals (chicken millet, field sorghum, bristle \\
grass) weeds
\end{tabular} & $\begin{array}{l}\text { Self-propelled sprayer } \\
\text { IBIS-2500-18P }\end{array}$ & - \\
\hline 40 & \begin{tabular}{|c|} 
Spraying of crops at a weed height of $10-15 \mathrm{~cm}$, regardless \\
of the phase of culture development with pesticides \\
Panther, EC $(40 \mathrm{~g} / 1)$ or Bagira, EC $(40 \mathrm{~g} / 1)$ with a rate of \\
$1.0-1.51(\mathrm{~kg}) /$ ha for control with perennial cereal \\
(wheatgrass creeping) weeds
\end{tabular} & $\begin{array}{l}\text { Self-propelled sprayer } \\
\text { IBIS-2500-18P }\end{array}$ & - \\
\hline
\end{tabular}




\begin{tabular}{|c|c|c|c|}
\hline 41 & $\begin{array}{c}\text { Spraying the soil before planting seedlings. Working fluid } \\
\text { consumption - } 200-3001 / \text { ha with pesticides Zino, SP (700 } \\
\mathrm{g} / \mathrm{kg}) \text { with a rate of } 1.1-1.41(\mathrm{~kg}) / \text { ha to combat annual } \\
\text { dicotyledonous and cereal weeds }\end{array}$ & $\begin{array}{l}\text { Self-propelled sprayer } \\
\text { IBIS-2500-18P }\end{array}$ & - \\
\hline 42 & $\begin{array}{l}\text { Spraying weeds with pesticides } 15-20 \text { days after planting } \\
\text { seedlings in the ground. Working fluid consumption - } 200- \\
300 \mathrm{l} / \mathrm{ha} \text { with pesticides Zino, SP }(700 \mathrm{~g} / \mathrm{kg}) \text { at a rate of } 1.0 \\
1(\mathrm{~kg}) / \text { ha to combat annual dicotyledonous and cereal weeds }\end{array}$ & $\begin{array}{l}\text { Self-propelled sprayer } \\
\text { IBIS-2500-18P }\end{array}$ & - \\
\hline 43 & $\begin{array}{l}\text { Protection of crops from pests with the insecticide Aktara, } \\
\text { VDG in two ways: under the root by the method of } \\
\text { fertigation through a drip irrigation system with a } \\
\text { consumption rate of } 0.4 \mathrm{~kg} / \mathrm{ha} \text { and a working fluid } \\
\text { consumption of } 2500-5000 \mathrm{l} / \mathrm{ha} \text {; spraying during the } \\
\text { growing season with the rate of consumption of the drug } \\
0.08-0.12 \mathrm{~kg} / \mathrm{ha} \text { and the consumption of working fluid } 200 \text { - } \\
400 \mathrm{l} / \mathrm{ha}\end{array}$ & $\begin{array}{l}\text { Under the root - drip } \\
\text { irrigation system } \\
\text { Spraying - Self- } \\
\text { propelled sprayer } \\
\text { IBIS-2500-18P }\end{array}$ & - \\
\hline 44 & Tomato harvest & MTZ-1221 & $\begin{array}{l}\text { Platform for } \\
\text { harvesting and } \\
\text { planting seedlings } \\
\text { of vegetables } \\
\text { PUO-1A }\end{array}$ \\
\hline 45 & Cleaning of plastic mulch film and drip tape & MTZ-1221 & $\begin{array}{l}\text { GDM EzyLift } \\
\text { Plastic Mulch } \\
\quad \text { Lifter }\end{array}$ \\
\hline 46 & $\begin{array}{l}\text { Preservation and dismantling of the drip irrigation system, } \\
\text { including the fertigation system (without removing the drip } \\
\text { tape) }\end{array}$ & \multicolumn{2}{|c|}{ Manually } \\
\hline 47 & $\begin{array}{c}\text { Removal of elements of the drip irrigation and fertigation } \\
\text { system }\end{array}$ & MTZ-1221 & 2 PTS-4 \\
\hline 48 & Peeling in two tracks to a depth of $0.06-0.08 \mathrm{~m}$ & MTZ-1221 & LDS-2,5 \\
\hline \multicolumn{4}{|c|}{ Spring-Autumn 2017} \\
\hline 49 & Restoring the geometry of ridges & DT-75M & MK-17 \\
\hline 50 & Rolling the soil of the ridges & MTZ-1221 & KVG-1,4 \\
\hline 51 & $\begin{array}{c}\text { Delivery of drip irrigation and fertigation system elements } \\
\text { (pumps, filters for fine and coarse water purification, water } \\
\text { meter, liflet hose, drip tape, taps, valves, tees, splitters, } \\
\text { plugs, injector, fertilizer tank, etc.) }\end{array}$ & MTZ-1221 & 2 PTS-4 \\
\hline 52 & $\begin{array}{c}\text { Drip irrigation system assembly including fertigation } \\
\text { system (no drip tape laying) }\end{array}$ & \multicolumn{2}{|c|}{ Manually } \\
\hline 53 & $\begin{array}{l}\text { Laying of Netafim drip tapes, water consumption of each } \\
\text { dropper } 1.8 \mathrm{l} / \mathrm{h} \text {, diameter and wall thickness of the drip tape } \\
-16 \mathrm{~mm} \text { and } 0.2 \mathrm{~mm} \text {, respectively, distance between } \\
\text { droppers } 0.2 \mathrm{~m} \text {, distance between drip lines }-0.24 \mathrm{~m}\end{array}$ & MTZ-1221 & $\begin{array}{l}\text { Drip irrigation tube } \\
\text { unwinder TM } \\
\text { "GreenBull" }\end{array}$ \\
\hline
\end{tabular}




\begin{tabular}{|c|c|c|c|}
\hline 54 & $\begin{array}{l}\text { Single pre-sowing treatment of seeds with a growth } \\
\text { regulator "Albit" at a dose of 50-100 } \mathrm{ml} / \mathrm{t}\end{array}$ & \multicolumn{2}{|c|}{ Manually } \\
\hline 55 & $\begin{array}{l}\text { Planting rice seedlings (Rapan variety) in nutrient pots in a } \\
\text { phytotron, a mixture of various components is used as a } \\
\text { substrate: highly fertile field land, sod land, humus, high } \\
\text { peat, coarse sand with the addition of microelements to the } \\
\text { substrate before planting rice seeds with a norm of } \\
\mathrm{N}_{80} \mathrm{P}_{120} \mathrm{~K}_{60} \text { in } \mathrm{kg} \text { a.d./ha, the humus content in the substrate } \\
\text { is not less than } 40 \% \text {, the substrate density is less than one, } \\
\text { the porosity is } 60-90 \% \text {, the air content is not less than } 10 \% \text {. } \\
\text { Maintaining the temperature regime: in the daytime } 20-24^{\circ} \\
\mathrm{C} \text {, in cloudy weather - } 16-18^{\circ} \mathrm{C} \text {, at night }-15-16^{\circ} \mathrm{C} \text {, } \\
\text { optimal pre-irrigation humidity - at the level of } 55-65 \% \text { of } \\
\text { HB, relative humidity - } 60-70 \% \text {. To maintain a stable } \\
\text { regime when these parameters were increased, ventilation } \\
\text { was switched on. During the period of growing seedlings, } \\
\text { the lighting was controlled using fluorescent lamps and } \\
\text { turned off at night. Seedlings in the phase of } 2-3 \text { leaves } \\
\text { were fed with nitrogen fertilizers in dissolved form at the } \\
\text { rate of } \mathrm{N}_{40} \text { in kg a.i./ha. Before planting in the ground, the } \\
\text { seedlings corresponded to the standard, had } 6-7 \text { leaves with } \\
\text { a green color, with a well-developed root system and not } \\
\text { infected with pests and diseases. }\end{array}$ & \multicolumn{2}{|c|}{ Manually } \\
\hline 56 & $\begin{array}{c}\text { Pre-planting irrigation with an irrigation rate providing soil moisture } \\
\text { of } 90 \% \text { of HB in a layer of } 0.6 \mathrm{~m}\end{array}$ & \multicolumn{2}{|c|}{ Drip irrigation system } \\
\hline 57 & $\begin{array}{c}\text { Spraying the soil surface with soil herbicides: "Ordram" } \\
720 \mathrm{EC}(5.01 / \text { ha, treatment rate } 1)+\text { Gezagard with a rate } \\
\text { of } 60-80 \mathrm{ml} / 10 \text { l of water to combat annual dicotyledonous } \\
\text { and cereal weeds }\end{array}$ & $\begin{array}{l}\text { Self-propelled sprayer } \\
\text { IBIS-2500-18P }\end{array}$ & - \\
\hline 58 & Shelter of ridges with perforated polyethylene mulch film & MTZ-1221 & - \\
\hline 59 & $\begin{array}{c}\text { Spraying BAS "Epin Extra" in the norm of 5-6 drops per } \\
0.51 \text { of water two days before planting seedlings to increase } \\
\text { survival rate and increase stress resistance }\end{array}$ & $\begin{array}{l}\text { Cordless sprayer } \\
\text { Clever } \\
\text { OE-12.5L-N }\end{array}$ & - \\
\hline 60 & \begin{tabular}{|l|} 
Planting rice seedlings \\
\end{tabular} & MTZ-1221 & - \\
\hline 61 & $\begin{array}{l}\text { Drip irrigation of rice through a drip irrigation system } \\
\text { during the growing season of rice with the frequency and } \\
\text { rate of irrigation depending on compliance with the } \\
\text { condition for ensuring constant soil moisture } 80 \% \text { of HB in } \\
\text { a layer of } 0.4 \mathrm{~m}\end{array}$ & \multicolumn{2}{|c|}{ Drip irrigation system } \\
\hline 62 & $\begin{array}{c}\text { Introduction of microelements after complete survival of } \\
\text { rice seedlings (in the phase of } 8-9 \text { leaves) by fertigation } \\
\text { through a drip irrigation system with a rate of } \mathrm{N}_{30} \mathrm{P}_{30} \mathrm{~K}_{30} \text { in } \\
\mathrm{kg} \text { a.d./ha }\end{array}$ & \multicolumn{2}{|c|}{ Drip irrigation system } \\
\hline 63 & $\begin{array}{c}\text { Treatment with herbicides Bazagran, v.r., (bentazone, } 480 \\
\text { g/l), "BASF AG" of rice crops in the tillering phase, with a } \\
\text { consumption rate of } 2.0-4.01 / \text { ha and a working fluid } \\
\text { consumption of } 200-3001 / \text { ha }\end{array}$ & $\begin{array}{l}\text { Self-propelled sprayer } \\
\text { IBIS-2500-18P }\end{array}$ & - \\
\hline 64 & $\begin{array}{l}\text { Spraying of seedlings of young seedlings of BAS "Albid" at } \\
\text { the end of tillering before the start of emergence into the } \\
\text { tube at a dose of } 30 \mathrm{mg} / \mathrm{ha} \text { to prevent lodging }\end{array}$ & $\begin{array}{l}\text { Self-propelled sprayer } \\
\text { IBIS-2500-18P }\end{array}$ & - \\
\hline 65 & $\begin{array}{c}\text { Introduction of microelements into the tillering phase of } \\
\text { rice by the method of fertigation through a drip irrigation } \\
\text { system with the norm } \mathrm{N}_{30} \text { in } \mathrm{kg} \text { a.d./ha }\end{array}$ & \multicolumn{2}{|c|}{ Drip irrigation system } \\
\hline 66 & $\begin{array}{l}\text { Treatment with fungicides in the phase of entering the tube } \\
\text { for prophylaxis (blast, fusarium, septoria), Kolosal, EC } \\
(250 \mathrm{~g} / \mathrm{l}) \text { rate } 0.75 \mathrm{l} / \mathrm{ha}\end{array}$ & $\begin{array}{l}\text { Self-propelled sprayer } \\
\text { IBIS-2500-18P }\end{array}$ & - \\
\hline 67 & Rice harvesting & $\begin{array}{l}\text { Harvester } \\
\text { Don } 1500\end{array}$ & - \\
\hline 68 & Transfer of rice seeds & $\begin{array}{l}\text { Kamaz grain carrier } \\
6360\end{array}$ & - \\
\hline 69 & Unloading pea seeds from the storage (Prizer variety) & - & $\begin{array}{c}\text { Electric motor }+ \\
\text { PShP 4A }\end{array}$ \\
\hline
\end{tabular}




\begin{tabular}{|c|c|c|c|}
\hline 70 & \begin{tabular}{|c|} 
Pea seed dressing 2 weeks before planting with Fundazol, \\
$50 \% \mathrm{c}$. $\mathrm{p}$ - $-2 \mathrm{~kg} / \mathrm{t}$, with the addition of microelements to the \\
dressing solution: boric acid $-300 \mathrm{~g} / \mathrm{t}$, ammonium \\
molybdate $-250 \mathrm{~g} / \mathrm{t}$, with obligatory humidification at a \\
water consumption of $5-101 / \mathrm{t}$ and the use of adhesives \\
(NaKMC- $200 \mathrm{~g} / \mathrm{t})$
\end{tabular} & - & PS-10A \\
\hline 71 & $\begin{array}{c}\text { Pre-planting irrigation with an irrigation rate providing soil } \\
\text { moisture of } 80 \% \text { of HB in a layer of } 0.8 \mathrm{~m}\end{array}$ & \multicolumn{2}{|c|}{ Drip irrigation system } \\
\hline 72 & $\begin{array}{l}\text { Spraying with herbicides on vegetative weeds after } \\
\text { harvesting the predecessor (rice) to combat perennial } \\
\text { cereals: creeping wheatgrass, sow thistle and thistle and } \\
\text { dicotyledonous plants. Roundup, } 360 \mathrm{~g} / 1 \mathrm{f} \text {.th.; dominator, } \\
\text { BP, glyphogan, BP; glialka, } 360 \mathrm{~g} / \mathrm{l} \text { f.th. and others - } 4-6 \\
\text { 1/ha or roundup, } 360 \mathrm{~g} / \mathrm{l} \text { f.th. }+2.4-\mathrm{D}-2+1.5-21 \text {, kg/ha }\end{array}$ & $\begin{array}{l}\text { Self-propelled sprayer } \\
\text { IBIS-2500-18P }\end{array}$ & - \\
\hline 73 & $\begin{array}{c}\text { Treatment of pea seeds on the day of sowing with } \\
\text { rhizotorphin at a rate of } 1 \mathrm{l} / \mathrm{kg} \text { per } 1 \text { ton or sapronite- } 1 \text { at a } \\
\text { rate of } 200 \mathrm{ml} \text { per hectare seed rate with the addition of } 2 \\
\text { liters of water }\end{array}$ & - & PS-10A \\
\hline 74 & Transporting seeds with loading seeders & GAZ-SAZ-53B & \\
\hline 75 & Planting seed peas to a depth of $4-5 \mathrm{~cm}$ & MTZ-1221 & $\begin{array}{c}\text { seeder } \\
\text { ForigoModula }\end{array}$ \\
\hline 76 & $\begin{array}{c}\text { Drip irrigation of peas through a drip irrigation system } \\
\text { during the growing season with the frequency and rate of } \\
\text { irrigation depending on compliance with the condition of } \\
\text { ensuring constant soil moisture of } 70-80 \% \text { of HB in a layer } \\
\text { of } 0.6 \mathrm{~m}\end{array}$ & \multicolumn{2}{|c|}{ Drip irrigation system } \\
\hline 77 & $\begin{array}{c}\text { The introduction of trace elements on the next day after } \\
\text { planting peas by fertigation through a drip irrigation system } \\
\text { by the norm } \mathrm{N}_{80} \mathrm{P}_{80} \mathrm{~K}_{80}\end{array}$ & \multicolumn{2}{|c|}{ Drip irrigation system } \\
\hline 78 & \begin{tabular}{|c|} 
Spraying with herbicide gesagard of the soil before pea \\
shoots. Consumption rate of the drug, $2.5-3.01, \mathrm{~kg} / \mathrm{ha}$. \\
Working fluid consumption $-200-300 \mathrm{l} / \mathrm{ha}$. For the control \\
of annual dicotyledonous and cereal weeds
\end{tabular} & $\begin{array}{l}\text { Self-propelled sprayer } \\
\text { IBIS-2500-18P }\end{array}$ & - \\
\hline 79 & $\begin{array}{c}\text { Spraying with herbicide of pea crops in the phase of } 1-3 \\
\text { leaves by Pulsar, BP }(40 \mathrm{~g} / \mathrm{l})(\mathrm{imazamox}) \text { with a } \\
\text { consumption rate of } 0.75-1.0 \mathrm{~kg}(\mathrm{l}) / \mathrm{ha} \text { to combat annual } \\
\text { cereals and dicotyledons }\end{array}$ & $\begin{array}{l}\text { Self-propelled sprayer } \\
\text { IBIS-2500-18P }\end{array}$ & - \\
\hline 80 & $\begin{array}{l}\text { Spraying with herbicide of pea crops in the phase of 3-5 } \\
\text { leaves Herbitox, VRK ( } 500 \mathrm{~g} / \mathrm{l} \text { MCPP) or Agritox, VK ( } 500 \\
\mathrm{~g} / \mathrm{l} \mathrm{MCPA}) \text { with a consumption rate of the drug } 0.5-0.8 \\
\mathrm{~kg}(1) / \text { ha for the control of annual cereals and dicotyledons }\end{array}$ & $\begin{array}{l}\text { Self-propelled sprayer } \\
\text { IBIS-2500-18P }\end{array}$ & - \\
\hline 81 & $\begin{array}{c}\text { Herbicide spraying of pea crops in the phase of 5-6 leaves } \\
\text { of Bazagran, BP ( } 480 \mathrm{~g} / \mathrm{l}) \text { (bentazone) or Korsar, VRK }(480 \\
\mathrm{g} / \mathrm{l}) \text { (bentazop) with a consumption rate of } 2.0-3.0 \mathrm{~kg}(1) / \mathrm{ha} \\
\text { for the control of annual dicotyledons }\end{array}$ & $\begin{array}{l}\text { Self-propelled sprayer } \\
\text { IBIS-2500-18P }\end{array}$ & - \\
\hline 82 & $\begin{array}{c}\text { Herbicide spraying of crops irrespective of the phase of } \\
\text { peas in the phase of } 2-4 \text { leaves of annual cereal weeds: } \\
\text { Fuzilad Super, EC }(125 \mathrm{~g} / \mathrm{l}) \text { (fluazifop-P-butyl) with a } \\
\text { consumption rate of } 1.0-2.0 \mathrm{~kg}(1) / \mathrm{ha} \text {, Miura, EC }(125 \mathrm{~g} / \mathrm{l}) \\
\text { (quizalofon-P-ethyl) with a drug consumption rate of } 0.4- \\
0.8 \mathrm{~kg}(1) / \mathrm{ha} \text {, Fuzilad Forte, EC }(150 \mathrm{~g} / \mathrm{l})(\text { fluazifop-P-butyl) } \\
\text { with a drug consumption rate of } 0.75-1.0 \mathrm{~kg}(1) / \mathrm{ha}\end{array}$ & $\begin{array}{l}\text { Self-propelled sprayer } \\
\text { IBIS-2500-18P }\end{array}$ & - \\
\hline 83 & \begin{tabular}{|} 
Herbicide spraying of crops regardless of the culture phase \\
at $10-15 \mathrm{~cm}$ in wheatgrass: Panther $4 \%$ ae. $-1.0-1.5$ \\
$\mathrm{~kg}(1) / \mathrm{ha}$; Targasuper, $5 \% \mathrm{k} . \mathrm{e}$ - -2.0 ; fuselade new, $15 \% \mathrm{k} . \mathrm{e}$. \\
$-1.5-2.0 \mathrm{~kg}(1) / \mathrm{ha}$; zellek super, $10.6 \%$ ae. $-1.0 \mathrm{~kg}(1) / \mathrm{ha}$ \\
\end{tabular} & $\begin{array}{l}\text { Self-propelled sprayer } \\
\text { IBIS-2500-18P }\end{array}$ & - \\
\hline 84 & $\begin{array}{c}\text { Spraying of pea plants in the presence of } 15 \text { or more beetles } \\
\text { (root weevils) in crops is performed at the phase of the first } \\
\text { pair of true leaves with the insecticide Bulldok, EC - } 0.3 \text {; } \\
\text { decis, EC - 0.2; extra decis, EC - 0.04; vismethrin, } 25 \% \text { ae. } \\
-0.3 \mathrm{~kg}(1) / \text { ha }\end{array}$ & $\begin{array}{l}\text { Self-propelled sprayer } \\
\text { IBIS-2500-18P }\end{array}$ & - \\
\hline
\end{tabular}




\begin{tabular}{|c|c|c|c|}
\hline 85 & 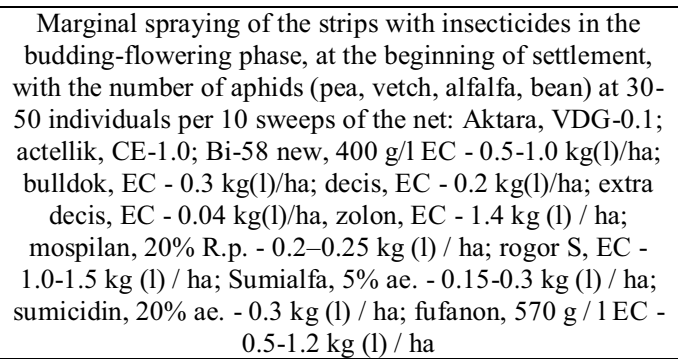 & $\begin{array}{l}\text { Self-propelled sprayer } \\
\text { IBIS-2500-18P }\end{array}$ & - \\
\hline 86 & $\begin{array}{l}\text { Spraying of pea crops during the growing season when pea } \\
\text { thrips is detected with Aktara insecticide, WDG - } 0.1 \\
\qquad \mathrm{~kg}(1) / \mathrm{ha}\end{array}$ & $\begin{array}{l}\text { Self-propelled sprayer } \\
\text { IBIS-2500-18P }\end{array}$ & - \\
\hline 87 & $\begin{array}{l}\text { Spraying of pea crops with an insecticide in the absence of } \\
\text { aphids in the crops during the mass summer and egg laying } \\
\text { of the pea moth in the budding - flowering phase: } \\
\text { Trichogramma twice, } 50 \text { thousand individuals per } 1 \text { ha }\end{array}$ & $\begin{array}{l}\text { Self-propelled sprayer } \\
\text { IBIS-2500-18P }\end{array}$ & - \\
\hline 88 & $\begin{array}{c}\text { Spraying pea crops with an insecticide when more than } 6 \\
\text { males are caught on a pheromone trap per week during the } \\
\text { mass summer and egg laying of the pea moth in the } \\
\text { budding - flowering phase: } \mathrm{Bi}-58 \mathrm{new}, 400 \mathrm{~g} / \mathrm{L} \text { aq. }-0.5- \\
1.0 \mathrm{~kg}(\mathrm{l}) / \mathrm{ha} \text {; danadim, } 400 \mathrm{~g} / \mathrm{l} \text { ae. }-0.8-1.0 \mathrm{~kg}(1) / \mathrm{ha} \text {; rogor } \\
\mathrm{S}, \mathrm{EC}-0.5-1.0 \mathrm{~kg}(1) / \mathrm{ha} \text {; fufanon, } 570 \mathrm{~g} / \mathrm{EC}-0.5-1.2 \\
\mathrm{~kg}(1) / \mathrm{ha}\end{array}$ & $\begin{array}{l}\text { Self-propelled sprayer } \\
\text { IBIS-2500-18P }\end{array}$ & - \\
\hline 89 & $\begin{array}{l}\text { Spraying pea crops with an insecticide when the first signs } \\
\text { of disease appear (gray rot peronosporosis, ascochitosis) in } \\
\text { the budding - flowering phase: Rex, } 49.7 \% \mathrm{c} . \mathrm{w} .-0.6 \\
\mathrm{~kg}(1) / \mathrm{ha}+\text { trace elements: copper sulfate, } 300 \mathrm{~g} / \mathrm{ha}+\mathrm{zinc} \\
\text { sulfate, } 350 \mathrm{~g} / \mathrm{ha} \text {; agate- } 25 \mathrm{~K}-0.04 \mathrm{~kg}(1) / \mathrm{ha} \text {; sumilex } 50 \% \\
\text { s.p. }-2-3 \mathrm{~kg}(1) / \mathrm{ha} \\
\end{array}$ & $\begin{array}{l}\text { Self-propelled sprayer } \\
\text { IBIS-2500-18P }\end{array}$ & - \\
\hline 90 & $\begin{array}{l}\text { Spraying pea crops with an insecticide when the first signs } \\
\text { of disease appear (powdery mildew) in the budding - } \\
\text { flowering phase: PSK, } 25 \% \text { bw. }-2-4 \mathrm{~kg}(1) / \mathrm{ha}\end{array}$ & $\begin{array}{l}\text { Self-propelled sprayer } \\
\text { IBIS-2500-18P }\end{array}$ & - \\
\hline 91 & $\begin{array}{c}\text { Desiccation of pea crops } 7-10 \text { days before harvesting is } \\
\text { performed at the yellowing phase of } 2 / 3 \text { of the beans on the } \\
\text { plant for pre-harvest drying of the harvested mass and } \\
\text { reducing the moisture content of pea seeds by } 20-25 \% \text {, } \\
\text { super raglon, BP - } 21 / \text { ha; basta, VR - } 1-21 / \text { ha; roundup, } \\
360 \mathrm{~g} / 1 \text { f.th. - } 3-41 / \text { ha. Working fluid consumption - } 200 \\
\text { 1/ha }\end{array}$ & $\begin{array}{l}\text { Self-propelled sprayer } \\
\text { IBIS-2500-18P }\end{array}$ & - \\
\hline 92 & Peas harvest & $\begin{array}{l}\text { Harvester } \\
\text { Don } 1500\end{array}$ & - \\
\hline 93 & Removal of pea seeds & $\begin{array}{c}\text { Kamaz grain carrier } \\
6360 \\
\end{array}$ & - \\
\hline 94 & Cleaning of plastic mulch film and drip tape & MTZ-1221 & \begin{tabular}{|c}
$\begin{array}{c}\text { GDM EzyLift Plastic } \\
\text { Mulch Lifter }\end{array}$ \\
\end{tabular} \\
\hline 95 & $\begin{array}{l}\text { Preservation and disassembly of the drip irrigation system, } \\
\text { including the fertigation system (without removing the drip } \\
\text { tape) }\end{array}$ & \multicolumn{2}{|c|}{ Manually } \\
\hline 96 & $\begin{array}{c}\text { Removal of elements of the drip irrigation and fertigation } \\
\text { system }\end{array}$ & MTZ-1221 & 2 PTS-4 \\
\hline 97 & Peeling in two tracks to a depth of $0.06-0.08 \mathrm{~m}$ & MTZ-1221 & LDS-2,5 \\
\hline \multicolumn{4}{|c|}{ Spring-Autumn 2018} \\
\hline 98 & Restoring the geometry of ridges & DT-75M & MK-17 \\
\hline 99 & Rolling the soil of the ridges & MTZ-1221 & KVG-1,4 \\
\hline 100 & $\begin{array}{c}\text { Delivery of drip irrigation and fertigation system elements } \\
\text { (pumps, filters for fine and coarse water purification, water } \\
\text { meter, liflet hose, drip tape, taps, valves, tees, splitters, } \\
\text { plugs, injector, fertilizer tank, etc.) }\end{array}$ & MTZ-1221 & 2 PTS-4 \\
\hline
\end{tabular}




\begin{tabular}{|c|c|c|c|}
\hline 101 & $\begin{array}{c}\text { Drip irrigation system assembly including fertigation } \\
\text { system (no drip tape laying) }\end{array}$ & \multicolumn{2}{|c|}{ Manually } \\
\hline 102 & $\begin{array}{l}\text { Laying of Netafim drip tapes, water consumption of each } \\
\text { dropper } 1.8 \mathrm{l} / \mathrm{h} \text {, diameter and wall thickness of the drip tape } \\
-16 \mathrm{~mm} \text { and } 0.2 \mathrm{~mm} \text {, respectively, distance between } \\
\text { droppers } 0.2 \mathrm{~m} \text {, distance between drip lines }-0.24 \mathrm{~m}\end{array}$ & MTZ-1221 & $\begin{array}{l}\text { Drip irrigation tube } \\
\text { unwinder TM } \\
\text { "GreenBull" }\end{array}$ \\
\hline 103 & $\begin{array}{l}\text { Single pre-sowing treatment of seeds with a growth } \\
\text { regulator "Albit" at a dose of } 50-100 \mathrm{ml} / \mathrm{t}\end{array}$ & \multicolumn{2}{|c|}{ Manually } \\
\hline 104 & $\begin{array}{l}\text { Planting rice seedlings (Rapan variety) in nutrient pots in a } \\
\text { phytotron, a mixture of various components is used as a } \\
\text { substrate: highly fertile field land, sod land, humus, high } \\
\text { peat, coarse sand with the addition of microelements to the } \\
\text { substrate before planting rice seeds with a norm of } \\
\text { N80P120K60 in kg a.d./ha, the humus content in the } \\
\text { substrate is not less than } 40 \% \text {, the substrate density is less } \\
\text { than one, the porosity is } 60-90 \% \text {, the air content is not less } \\
\text { than } 10 \% \text {. Maintaining the temperature regime: in the } \\
\text { daytime } 20-24^{\circ} \mathrm{C} \text {, in cloudy weather - } 16-18^{\circ} \mathrm{C} \text {, at night - } \\
15-16^{\circ} \mathrm{C} \text {, optimal pre-irrigation humidity - at the level of } \\
55-65 \% \text { of HB, relative humidity - } 60-70 \% \text {. To maintain a } \\
\text { stable regime when these parameters were increased, } \\
\text { ventilation was switched on. During the period of growing } \\
\text { seedlings, the lighting was controlled using fluorescent } \\
\text { lamps and turned off at night. Seedlings in the phase of } 2-3 \\
\text { leaves were fed with nitrogen fertilizers in dissolved form } \\
\text { at the rate of } \mathrm{N}_{40} \text { in kg ai / ha. Before planting in the } \\
\text { ground, the seedlings corresponded to the standard, had } 6-7 \\
\text { leaves with a green color, with a well-developed root } \\
\text { system and not infected with pests and diseases. }\end{array}$ & \multicolumn{2}{|c|}{ Manually } \\
\hline 105 & $\begin{array}{c}\text { Pre-planting irrigation with an irrigation rate providing soil } \\
\text { moisture of } 90 \% \text { of HB in a layer of } 0.6 \mathrm{~m}\end{array}$ & \multicolumn{2}{|c|}{ Drip irrigation system } \\
\hline 106 & $\begin{array}{c}\text { Spraying the soil surface with soil herbicides: "Ordram" } \\
720 \text { EC }(5.01 / \text { ha, treatment rate } 1)+\text { Gezagard with a rate } \\
\text { of } 60-80 \mathrm{ml} / 101 \text { of water to combat annual } \\
\text { dicotyledonous and cereal weeds }\end{array}$ & $\begin{array}{l}\text { Self-propelled sprayer } \\
\text { IBIS-2500-18P }\end{array}$ & \\
\hline 107 & Shelter of ridges with perforated polyethylene mulch film & MTZ-1221 & \\
\hline 108 & $\begin{array}{c}\text { Spraying BAS "Epin Extra" in the norm of 5-6 drops per } \\
0.51 \text { of water two days before planting seedlings to increase } \\
\text { survival rate and increase stress resistance }\end{array}$ & $\begin{array}{l}\text { Cordless sprayer } \\
\text { Clever } \\
\text { OE-12.5L-N }\end{array}$ & \\
\hline 109 & Planting rice seedlings & MTZ-1221 & \\
\hline 110 & $\begin{array}{c}\text { Drip irrigation of rice through a drip irrigation system } \\
\text { during the growing season of rice with the frequency and } \\
\text { rate of irrigation depending on compliance with the } \\
\text { condition for ensuring constant soil moisture } 80 \% \text { of HB in } \\
\text { a layer of } 0.4 \mathrm{~m}\end{array}$ & \multicolumn{2}{|c|}{ Drip irrigation system } \\
\hline 111 & $\begin{array}{c}\text { The introduction of microelements after complete survival } \\
\text { of rice seedlings (in the phase of } 8-9 \text { leaves) by fertigation } \\
\text { through a drip irrigation system is normal } \mathrm{N}_{30} \mathrm{P}_{30} \mathrm{~K}_{30} \text { in } \\
\text { a.d./ha }\end{array}$ & \multicolumn{2}{|c|}{ Drip irrigation system } \\
\hline 112 & $\begin{array}{c}\text { Treatment with herbicides Bazagran, v.r., (bentazone, } 480 \\
\text { g/l), "BASF AG" of rice crops in the tillering phase, with a } \\
\text { consumption rate of } 2.0-4.01 / \text { ha and a working fluid } \\
\text { consumption of } 200-300 \mathrm{l} / \mathrm{ha}\end{array}$ & $\begin{array}{l}\text { Self-propelled sprayer } \\
\text { IBIS-2500-18P }\end{array}$ & \\
\hline 113 & $\begin{array}{c}\text { Spraying of seedlings of young seedlings of BAS "Albid" at } \\
\text { the end of tillering before the start of emergence into the } \\
\text { tube at a dose of } 30 \mathrm{mg} / \text { ha to prevent lodging }\end{array}$ & $\begin{array}{l}\text { Self-propelled sprayer } \\
\text { IBIS-2500-18P }\end{array}$ & \\
\hline 114 & $\begin{array}{l}\text { Introduction of microelements into the tillering phase of } \\
\text { rice by the method of fertigation through a drip irrigation } \\
\text { system with the norm } \mathrm{N}_{30} \text { in } \mathrm{kg} \text { a.d./ha }\end{array}$ & \multicolumn{2}{|c|}{ Drip irrigation system } \\
\hline 115 & $\begin{array}{l}\text { Treatment with fungicides in the phase of coming out into } \\
\text { the tube for prophylaxis (blast, fusarium, septoria), Kolosal, } \\
\text { EC }(250 \mathrm{~g} / 1) \text { rate } 0.751 / \mathrm{ha}\end{array}$ & $\begin{array}{l}\text { Self-propelled sprayer } \\
\text { IBIS-2500-18P }\end{array}$ & \\
\hline
\end{tabular}




\begin{tabular}{|c|c|c|c|}
\hline 116 & Rice harvesting & $\begin{array}{l}\text { Harvester } \\
\text { Don } 1500 \\
\end{array}$ & - \\
\hline 117 & Transfer of rice seeds & $\begin{array}{c}\text { Kamaz grain carrier } \\
6360\end{array}$ & - \\
\hline 118 & \begin{tabular}{|} 
Presowing soaking of pepper seeds of the "Red Bison" \\
variety for $2-3$ days, while at the last hour the pepper seeds \\
are soaked in a solution of the biological product \\
Fitosporin-M with a rate of $1.5 \mathrm{~g}$ per 11 of water
\end{tabular} & \multicolumn{2}{|c|}{ Manually } \\
\hline 119 & $\begin{array}{c}\text { Planting pepper seeds } 50-65 \text { days before planting in open } \\
\text { ground, planting is carried out in peat cups with a cross } \\
\text { section of at least } 100 \mathrm{~mm} \text { to a depth of } 0.5-1.0 \mathrm{~cm} \text { in "BIO } \\
\text { Soil Ecoflora for Vegetables" from "Hera" and then } \\
\text { covered with foil at the same time, it is necessary to } \\
\text { observe the distance between the seedlings at least } 15 \mathrm{~cm} \\
\text { from each other, while the temperature in the soil is } \\
\text { maintained at } 27^{\circ} \mathrm{C}\left( \pm 20^{\circ} \mathrm{C}\right) \text {, the air temperature before } \\
\text { the emergence of shoots is } 28^{\circ} \mathrm{C} \text { around the clock, then } \\
\text { after the emergence of shoots until the formation of the } 1 \mathrm{st} \\
\text { leaf } 17^{\circ} \mathrm{C} \text { ( } \pm 1^{\circ} \mathrm{C} \text { ) around the clock, in the next plant } \\
\text { phases during the day } 23-28^{\circ} \mathrm{C} \text {, at night } 16-17^{\circ} \mathrm{C} \text {, the } \\
\text { temperature of irrigation water is } 25-30^{\circ} \mathrm{C} \text {; at the same } \\
\text { time, during the growing of seedlings, fertilizing is } \\
\text { performed, while for the first time fertilizers are applied at } \\
\text { the emergence phase } 1-2 \text { real sheets with the following } \\
\text { composition: dilute } 5 \text { grams in } 10 \text { liters of water ammonium } \\
\text { nitrate, } 10 \mathrm{~g} \text { potassium-based dressings, } 30 \mathrm{~g} \text {. } \\
\text { superphosphate fertilizers. The next feeding is in two weeks } \\
\text { according to the same scheme, but with a doubling of the } \\
\text { dosage. The third feeding is performed a couple of days } \\
\text { before planting the seedlings, in which the dosage of } \\
\text { potassium in the solution is increased to } 80 \mathrm{~g} \text { per } 101 \text { of } \\
\text { water, while during the growth of seedlings, soil moisture is } \\
\text { maintained at } 70 \% \text { of } \mathrm{HB} \text {, and before planting in the } \\
\text { ground, } 75 \% \text { of HB. }\end{array}$ & \multicolumn{2}{|c|}{ Manually } \\
\hline 120 & \begin{tabular}{|c|} 
Treatment with a pesticide (systemic fungicide) \\
propamocarb hydrochloride $3-4$ days before planting \\
seedlings at a concentration of $607 \mathrm{~g} / \mathrm{l}$ and a consumption \\
rate of $15 \mathrm{ml}$ per 101 of water to combat soil, root and leaf \\
diseases
\end{tabular} & \multicolumn{2}{|c|}{ Drip irrigation system } \\
\hline 121 & $\begin{array}{c}\text { Application of herbicide Treflan, } 24 \%(3.6-4.81 / \text { ha) } 12-14 \\
\text { days before planting seedlings to combat annual cereals and } \\
\text { a number of dicotyledonous weeds }\end{array}$ & \multicolumn{2}{|c|}{ Drip irrigation system } \\
\hline 122 & $\begin{array}{l}\text { Pre-planting irrigation with the introduction of mineral } \\
\text { fertilizers based on potassium, nitrogen and phosphates at } \\
\text { the rate of } 30 \text { grams per } 1 \mathrm{~m}^{2} \text { by fertigation through a drip } \\
\text { irrigation system and an irrigation rate providing soil } \\
\text { moisture of } 90 \% \text { of HB in a layer of } 0.8 \mathrm{~m}\end{array}$ & \multicolumn{2}{|c|}{ Drip irrigation system } \\
\hline 123 & $\begin{array}{c}\text { Planting seedlings in open ground (a bush of seedlings } \\
\text { before planting in open ground should be at least } 20 \mathrm{~cm} \\
\text { high, have up to } 12 \text { well-developed leaves and developing } \\
\text { inflorescences, and the crown bud should be removed), } \\
\text { while the rice stubble is removed and a peat bush is placed } \\
\text { in the formed hole a pot of pepper seedlings with a light } \\
\text { compaction of the soil }\end{array}$ & MTZ-1221 & $\begin{array}{l}\text { Platform for } \\
\text { harvesting and } \\
\text { planting seedlings } \\
\text { of vegetables } \\
\text { PUO-1A }\end{array}$ \\
\hline 124 & $\begin{array}{c}\text { Introduction of biostimulants for the development of the } \\
\text { root system } 10-12 \text { days after transplanting pepper seedlings } \\
\text { at the rate of } 30 \mathrm{ml} / 101 \text { of water with an interval of } 10-12 \\
\text { days }\end{array}$ & \multicolumn{2}{|c|}{ Drip irrigation system } \\
\hline 125 & $\begin{array}{c}\text { Introduction of biopreparations and growth stimulants } 10- \\
12 \text { days after transplanting pepper seedlings at the rate of } \\
30 \mathrm{ml} / 101 \text { of water and then at the same rate every } 5-10 \\
\text { days to protect plants from stress }\end{array}$ & \multicolumn{2}{|c|}{ Drip irrigation system } \\
\hline
\end{tabular}




\begin{tabular}{|c|c|c|c|}
\hline 126 & $\begin{array}{l}\text { Foliar application on the Omex } 3 \times \text { leaf }(50 \mathrm{ml} / 101 \text { of } \\
\text { water) at intervals of } 3-7 \text { days }\end{array}$ & $\begin{array}{l}\text { Self-propelled sprayer } \\
\text { IBIS-2500-18P }\end{array}$ & \\
\hline 127 & $\begin{array}{l}\text { Top dressing with ammonium nitrate } 75 \mathrm{~g} / 101 \text { of water at } \\
\text { intervals of 3-7 days }\end{array}$ & \multicolumn{2}{|c|}{ Drip irrigation system } \\
\hline 128 & $\begin{array}{l}\text { Two-time spraying with Fitoverma insecticide (thrips, } \\
\text { mealybug and spider mite), consumption of } 10 \mathrm{ml} \text { per } 1 \\
\text { liter of water }\end{array}$ & $\begin{array}{l}\text { Self-propelled sprayer } \\
\text { IBIS-2500-18P }\end{array}$ & \\
\hline 129 & $\begin{array}{l}\text { Single spraying with an insecticide (aphid), the } \\
\text { consumption of the product is } 8 \mathrm{ml} \text { per } 1 \text { liter of water. }\end{array}$ & $\begin{array}{l}\text { Self-propelled sprayer } \\
\text { IBIS-2500-18P }\end{array}$ & \\
\hline 130 & $\begin{array}{l}\text { Drip irrigation of sweet pepper through a drip irrigation } \\
\text { system during the growing season with the frequency and } \\
\text { rate of irrigation depending on compliance with the } \\
\text { condition for ensuring constant moisture in the soil layer } \\
0.8-0.9 \mathrm{~m}: 80 \% \text { of HB during the growing season }\end{array}$ & \multicolumn{2}{|c|}{ Drip irrigation system } \\
\hline 140 & $\begin{array}{c}\text { Mineral fertilization during planting } \mathrm{N}_{80} \mathrm{P}_{160} \mathrm{~K}_{240} \text { (ratio NPK } \\
1: 2: 3 \text { ) then a week further after the first cleaning and then } \\
\text { every week } \mathrm{N}_{25} \mathrm{P}_{25} \mathrm{~K}_{25}\end{array}$ & \multicolumn{2}{|c|}{ Drip irrigation system } \\
\hline 141 & $\begin{array}{l}\text { Boron introduction at the rate of } 25-30 \mathrm{ml} / 10 \mathrm{l} \text { of water in } \\
\text { the flowering phase }\end{array}$ & \multicolumn{2}{|c|}{ Drip irrigation system } \\
\hline 142 & $\begin{array}{c}\text { Application of mineral fertilizers on a leaf - leaf } \\
\text { microfertilizers } 5: 15: 45(25 \mathrm{~g} / 101 \text { of water }) \text { with an } \\
\text { interval of } 4-10 \text { days }\end{array}$ & $\begin{array}{l}\text { Self-propelled sprayer } \\
\text { IBIS-2500-18P }\end{array}$ & - \\
\hline 143 & Harvesting sweet peppers & MTZ-1221 & \begin{tabular}{|} 
Platform for \\
harvesting and \\
planting seedlings \\
of vegetables \\
PUO-1A \\
\end{tabular} \\
\hline 144 & Cleaning of polyethylene mulching film and / or drip tape & MTZ-1221 & $\begin{array}{l}\text { GDM EzyLift } \\
\text { Plastic Mulch } \\
\quad \text { Lifter }\end{array}$ \\
\hline 145 & $\begin{array}{l}\text { Preservation and dismantling of the drip irrigation system, } \\
\text { including the fertigation system (without cleaning from the } \\
\text { drip tape ridges) }\end{array}$ & \multicolumn{2}{|c|}{ Manually } \\
\hline 146 & $\begin{array}{l}\text { Removal of elements of the drip irrigation and fertigation } \\
\text { system }\end{array}$ & MTZ-1221 & 2 PTS-4 \\
\hline 147 & Peeling in two tracks to a depth of $0.06-0.08 \mathrm{~m}$ & MTZ-1221 & LDS-2,5 \\
\hline & \multicolumn{3}{|c|}{ Spring-Autumn 2019} \\
\hline 148 & Restoring the geometry of ridges & DT-75M & MK-17 \\
\hline 149 & Rolling the soil of the ridges & MTZ-1221 & KVG-1,4 \\
\hline 150 & $\begin{array}{l}\text { Delivery of elements of the drip irrigation and fertigation } \\
\text { system (pumps, filters for fine and coarse water } \\
\text { purification, water meter, lifelet hose, drip tape, taps, } \\
\text { valves, tees, splitters, plugs, injector, fertilizer container) }\end{array}$ & MTZ-1221 & 2 PTS-4 \\
\hline 151 & $\begin{array}{l}\text { Drip irrigation system assembly including fertigation } \\
\text { system (no drip tape laying) }\end{array}$ & \multicolumn{2}{|c|}{ Manually } \\
\hline 152 & $\begin{array}{l}\text { Laying of Netafim drip tapes, water consumption of each } \\
\text { dropper } 1.8 \mathrm{l} / \mathrm{h} \text {, diameter and wall thickness of the drip tape } \\
-16 \mathrm{~mm} \text { and } 0.2 \mathrm{~mm} \text {, respectively, distance between } \\
\text { droppers } 0.2 \mathrm{~m} \text {, distance between drip lines }-0.24 \mathrm{~m}\end{array}$ & MTZ-1221 & $\begin{array}{l}\text { Drip irrigation tube } \\
\text { unwinder TM } \\
\text { "GreenBull" }\end{array}$ \\
\hline 153 & $\begin{array}{l}\text { Single pre-sowing treatment of seeds with a growth } \\
\text { regulator "Albit" at a dose of } 50-100 \mathrm{ml} / \mathrm{t}\end{array}$ & \multicolumn{2}{|c|}{ Manually } \\
\hline
\end{tabular}




\begin{tabular}{|c|c|c|c|}
\hline 154 & $\begin{array}{l}\text { Planting rice seedlings (Rapan variety) in nutrient pots in a } \\
\text { phytotron, a mixture of various components is used as a } \\
\text { substrate: highly fertile field land, sod land, humus, high } \\
\text { peat, coarse sand with the addition of microelements to the } \\
\text { substrate before planting rice seeds by the norm } \mathrm{N}_{80} \mathrm{P}_{120} \mathrm{~K}_{60} \\
\text { in kg a.d./ha, humus content in the substrate is not lower } 40 \\
\% \text {, the density of the substrate is less than one, the porosity } \\
\text { is } 60-90 \% \text {, the air content is not less than } 10 \% \text {. } \\
\text { Maintaining the temperature regime: during the day } 20-24^{\circ} \\
\mathrm{C} \text {, in cloudy weather - } 16-18^{\circ} \mathrm{C} \text {, at night }-15-16^{\circ} \mathrm{C} \text {, } \\
\text { optimal pre-irrigation humidity - at the level of } 55-65 \% \text { of } \\
\text { HB, relative air humidity - } 60-70 \% \text {. To maintain a stable } \\
\text { regime when these parameters were increased, ventilation } \\
\text { was switched on. During the period of seedling growing, } \\
\text { the lighting was controlled using fluorescent lamps and } \\
\text { turned off at night. Seedlings in the phase of } 2-3 \text { leaves } \\
\text { were fed with nitrogen fertilizers in dissolved form at the } \\
\text { rate of } \mathrm{N}_{40} \text { in kg a.d./ha. Before planting in the ground, the } \\
\text { seedlings corresponded to the standard, had } 6-7 \text { leaves with } \\
\text { a green color, with a well-developed root system and not } \\
\text { infected with pests and diseases }\end{array}$ & \multicolumn{2}{|c|}{ Manually } \\
\hline 155 & $\begin{array}{l}\text { Pre-planting irrigation with an irrigation rate providing soil } \\
\text { moisture of } 90 \% \text { of HB in a layer of } 0.6 \mathrm{~m}\end{array}$ & \multicolumn{2}{|c|}{ Drip irrigation system } \\
\hline 156 & $\begin{array}{c}\text { Spraying the soil surface with soil herbicides: "Ordram" } \\
720 \text { EC }(5.01 / \text { ha, treatment rate } 1)+\text { Gezagard with a rate } \\
\text { of } 60-80 \mathrm{ml} / 101 \text { of water to combat annual } \\
\text { dicotyledonous and cereal weeds }\end{array}$ & $\begin{array}{l}\text { Self-propelled sprayer } \\
\text { IBIS-2500-18P }\end{array}$ & \\
\hline 157 & Shelter of ridges with perforated polyethylene mulch film & MTZ-1221 & \\
\hline 158 & $\begin{array}{c}\text { Spraying BAS "Epin Extra" in the norm of } 5-6 \text { drops per } \\
0.51 \text { of water two days before planting seedlings to increase } \\
\text { survival rate and increase stress resistance }\end{array}$ & $\begin{array}{l}\text { Cordless sprayer } \\
\text { Clever } \\
\text { OE-12.5L-N }\end{array}$ & \\
\hline 159 & Planting rice seedlings & MTZ-1221 & \\
\hline 160 & $\begin{array}{l}\text { Drip irrigation of rice through a drip irrigation system } \\
\text { during the growing season of rice with the frequency and } \\
\text { rate of irrigation depending on compliance with the } \\
\text { condition for ensuring constant soil moisture } 80 \% \text { of } \mathrm{HB} \text { in } \\
\text { a layer of } 0.4 \mathrm{~m}\end{array}$ & \multicolumn{2}{|c|}{ Drip irrigation system } \\
\hline 161 & $\begin{array}{l}\text { The introduction of microelements after complete survival } \\
\text { of rice seedlings (in the phase of } 8-9 \text { leaves) by fertigation } \\
\text { through a drip irrigation system by the norm } \mathrm{N}_{30} \mathrm{P}_{30} \mathrm{~K}_{30} \text { in } \\
\qquad \mathrm{kg} \text { a.d./ha }\end{array}$ & \multicolumn{2}{|c|}{ Drip irrigation system } \\
\hline 162 & $\begin{array}{l}\text { Treatment with herbicides Bazagran, v.r., (bentazone, } 480 \\
\text { g/l), "BASF AG" of rice crops in the tillering phase, with a } \\
\text { consumption rate of } 2.0-4.01 / \text { ha and a working fluid } \\
\text { consumption of } 200-3001 / \text { ha }\end{array}$ & $\begin{array}{l}\text { Self-propelled sprayer } \\
\text { IBIS-2500-18P }\end{array}$ & \\
\hline 163 & $\begin{array}{l}\text { Spraying of seedlings of young seedlings of BAS "Albid" at } \\
\text { the end of tillering before the start of emergence into the } \\
\text { tube at a dose of } 30 \mathrm{mg} / \text { ha to prevent lodging }\end{array}$ & $\begin{array}{l}\text { Self-propelled sprayer } \\
\text { IBIS-2500-18P }\end{array}$ & \\
\hline 164 & $\begin{array}{l}\text { Introduction of microelements into the tillering phase of } \\
\text { rice by the method of fertigation through a drip irrigation } \\
\text { system with the norm } \mathrm{N}_{30} \text { in } \mathrm{kg} \text { a.d./ha }\end{array}$ & \multicolumn{2}{|c|}{ Drip irrigation system } \\
\hline 165 & $\begin{array}{l}\text { Treatment with fungicides in the phase of entering the tube } \\
\text { for prophylaxis (blast, fusarium, septoria), Kolosal, EC } \\
\qquad(250 \mathrm{~g} / \mathrm{l}) \text { rate } 0.75 \mathrm{l} / \mathrm{ha}\end{array}$ & $\begin{array}{l}\text { Self-propelled sprayer } \\
\text { IBIS-2500-18P }\end{array}$ & \\
\hline 166 & Rice harvesting & $\begin{array}{l}\text { Harvester } \\
\text { Don } 1500\end{array}$ & - \\
\hline 167 & Transfer of rice seeds & $\begin{array}{l}\text { Kamaz grain carrier } \\
6360 \\
\end{array}$ & - \\
\hline 168 & Unloading soybean seeds from storage (Irbis variety) & - & $\begin{array}{l}\text { Electric motor }+ \\
\text { PShP 4A }\end{array}$ \\
\hline
\end{tabular}




\begin{tabular}{|c|c|c|c|}
\hline 169 & \begin{tabular}{|c|} 
Treating soybean seeds with a fungicide on the day of \\
sowing with Fundazol, SP (Agro-Kemi Kft.) $(500 \mathrm{~g} / \mathrm{kg})$, \\
application rate $3 \mathrm{~kg} / \mathrm{t}$ or MAXIM, KS (Syngenta LLC) $(25$ \\
g/l) with consumption working fluid 7-8 $1 / \mathrm{t}$ with obligatory \\
moistening at a water consumption of $5-101 / \mathrm{t}$ and the use \\
of adhesives (NaKMTs-200 g/t)
\end{tabular} & - & PS-10A \\
\hline 170 & \begin{tabular}{|c|} 
Presowing treatment of soybean seeds with Agropon C \\
growth regulators, $\operatorname{HRV}(1 \mathrm{~g} / \mathrm{l})$, working fluid consumption \\
$10 \mathrm{l} / \mathrm{t}$ to enhance growth and development processes, \\
increase seed yield, increase fat and protein content and $/$ or \\
Mival Agro, KRP $(760+190 \mathrm{~g} / \mathrm{kg})$ at a rate of $15 \mathrm{~g} / \mathrm{t}$ to \\
increase the number of beans per plant and increase yields \\
\end{tabular} & - & PS-10A \\
\hline 171 & $\begin{array}{c}\text { Pre-planting irrigation with an irrigation rate providing soil } \\
\text { moisture of } 80 \% \text { of } \mathrm{HB} \text { in a layer of } 0.8 \mathrm{~m}\end{array}$ & \multicolumn{2}{|c|}{ Drip irrigation system } \\
\hline 172 & \begin{tabular}{|l|} 
Spraying with herbicides Trophy $90, \mathrm{EC}(900 \mathrm{~g} / \mathrm{l})$ before \\
sowing (with incorporation with a lack of moisture) or \\
before crop sprouting with a rate of application of $1.5-2.0$ \\
1/ha with a working fluid flow rate of $200-300 \mathrm{l} / \mathrm{ha}$ to \\
combat with annual cereals and some dicotyledonous weeds
\end{tabular} & $\begin{array}{l}\text { Self-propelled sprayer } \\
\text { IBIS-2500-18P }\end{array}$ & - \\
\hline 173 & Transportation of soybean seeds with loading seeders & GAZ-SAZ-53B & - \\
\hline 174 & Planting seed soybeans to a depth of $2-3 \mathrm{~cm}$ & MTZ-1221 & $\begin{array}{c}\text { seeder } \\
\text { ForigoModula }\end{array}$ \\
\hline 175 & $\begin{array}{c}\text { Drip irrigation of soybeans through a drip irrigation system } \\
\text { during the growing season with the frequency and rate of } \\
\text { irrigation depending on compliance with the condition of } \\
\text { ensuring constant soil moisture of } 70-80 \% \text { of HB in a layer } \\
\text { of } 0.6 \mathrm{~m}\end{array}$ & \multicolumn{2}{|c|}{ Drip irrigation system } \\
\hline 176 & $\begin{array}{l}\text { Application of mineral fertilizers on the next day after } \\
\text { planting soybeans by the method of fertigation through a } \\
\text { drip irrigation system as normal } \mathrm{N}_{20} \mathrm{P}_{30} \mathrm{~K}_{60}\end{array}$ & \multicolumn{2}{|c|}{ Drip irrigation system } \\
\hline 177 & $\begin{array}{c}\text { Spraying with herbicides Bazagran, BP } \\
(480 \mathrm{~g} / \mathrm{l}) \text { starting from the phase of the } 1 \mathrm{st} \text { true leaf of the } \\
\text { culture in the early phases of weed growth }(2-6 \text { leaves }) \text {, the } \\
\text { application rate is } 1.5-3.01 / \text { ha with a flow rate of the } \\
\text { working fluid }-200-3001 / \text { ha for control of annual } \\
\text { dicotyledonous weeds, incl. cocklebur }\end{array}$ & $\begin{array}{l}\text { Self-propelled sprayer } \\
\text { IBIS-2500-18P }\end{array}$ & - \\
\hline 178 & $\begin{array}{c}\text { Spraying with herbicides Zellek-super, EC }(104 \mathrm{~g} / \mathrm{l}) \text { during } \\
\text { the period of their active growth in the phase from } 2 \text { leaves } \\
\text { to tillering (regardless of the phase of crop development) } \\
\text { with a rate of application of } 0.51 / \text { ha with a working fluid } \\
\text { consumption of } 200-3001 / \text { ha for the control of annual } \\
\text { dicotyledonous weeds, incl. cocklebur }\end{array}$ & $\begin{array}{l}\text { Self-propelled sprayer } \\
\text { IBIS-2500-18P }\end{array}$ & - \\
\hline 179 & $\begin{array}{l}\text { Spraying with herbicides Fusilad Forte, EC }(150 \mathrm{~g} / \mathrm{l}) \text { in the } \\
\text { phase of } 2-4 \text { leaves (regardless of the phase of crop } \\
\text { development) with a rate of application of } 0.75-2.01 / \mathrm{ha} \\
\text { with a working fluid consumption of } 200-300 \mathrm{l} / \mathrm{ha} \text { to } \\
\text { combat with annual and perennial cereal weeds }\end{array}$ & $\begin{array}{l}\text { Self-propelled sprayer } \\
\text { IBIS-2500-18P }\end{array}$ & - \\
\hline 180 & $\begin{array}{c}\text { Spraying with herbicides Galaktion, EC (104 g/l) during the } \\
\text { period of their active growth (in the phase from } 2-6 \text { leaves } \\
\text { to tillering) with a rate of application of } 0.51 / \text { ha with a } \\
\text { working fluid consumption of } 200-3001 / \text { ha for fight against } \\
\text { annual millet (chicken millet, weed-field millet, types of } \\
\text { bristles) }\end{array}$ & $\begin{array}{l}\text { Self-propelled sprayer } \\
\text { IBIS-2500-18P }\end{array}$ & - \\
\hline 181 & $\begin{array}{c}\text { The introduction of microelements "Meristem NPK } \\
\text { 20:20:20" at the budding phase by fertigation through a drip } \\
\text { irrigation system at a rate of } 1.0-2.0 \mathrm{~kg} / \mathrm{ha}\end{array}$ & \multicolumn{2}{|c|}{ Drip irrigation system } \\
\hline
\end{tabular}




\begin{tabular}{|c|c|c|c|}
\hline 182 & $\begin{array}{l}\text { Spraying of soybeans with insecticides "Bi-58 new" } 40 \% \\
\text { eq. at a dose of } 1.0 \mathrm{l} / \mathrm{ha} \text { in the presence of spider mites and } \\
\text { acacia moths in the crops }\end{array}$ & $\begin{array}{l}\text { Self-propelled sprayer } \\
\text { IBIS-2500-18P }\end{array}$ & - \\
\hline 183 & $\begin{array}{c}\text { 2-3 times spraying of soybean crops with Sumicidin } \\
\text { insecticide, } 20 \% \text { eq. }(0.51 / \text { ha) for the extermination of the } \\
\text { acacia moth during the mass summer of the butterfly and } \\
\text { the laying of eggs }\end{array}$ & $\begin{array}{l}\text { Self-propelled sprayer } \\
\text { IBIS-2500-18P }\end{array}$ & - \\
\hline 184 & $\begin{array}{c}\text { Application of mineral fertilizers N6P26K18 (ammophos } \\
\text { and potassium chloride during sowing) }+4 \text { foliar dressings } \\
\text { (in the phases of formation of } 2-3 \text { leaves, budding, before } \\
\text { flowering and seed formation or ripening), consisting of a } \\
\text { complex water-soluble fertilizer "AgroMaster } 18-18-18+3 \\
\text { "containing } 18 \% \mathrm{~N}, 18 \% \mathrm{P}_{2} \mathrm{O}_{5} \text { and } 18 \% \mathrm{~K}_{2} \mathrm{O}, \mathrm{Mg}, \mathrm{S} \text { and } \\
\text { microelements }(\mathrm{B}, \mathrm{Cu}, \mathrm{Fe}, \mathrm{Mn}, \mathrm{Mo}, \mathrm{Zn}) \text { at a solution } \\
\text { concentration of } 0.53 \% \text { and consumption of } 200 \mathrm{l} / \mathrm{ha}(1.05 \\
\mathrm{kg} \text { of fertilizer/ha). }\end{array}$ & $\begin{array}{l}\text { Root dressing - drip } \\
\text { irrigation system } \\
\text { Foliar dressing - self- } \\
\text { propelled sprayer } \\
\text { IBIS-2500-18P }\end{array}$ & - \\
\hline 185 & $\begin{array}{l}\text { Desiccation of crops } 6 \text { days before harvesting is carried out } \\
\text { at the stage of the beginning of brown beans of the lower } \\
\text { and middle tiers for pre-harvest drying of the harvested } \\
\text { mass and reducing the moisture content of pea seeds by } 14- \\
16 \% \text {, Reglon forte, RK }-1.50-2.251 / \text { ha. Working fluid } \\
\text { consumption }-250-400 \mathrm{l} / \mathrm{ha}\end{array}$ & $\begin{array}{l}\text { Self-propelled sprayer } \\
\text { IBIS-2500-18P }\end{array}$ & - \\
\hline 186 & Soybean harvest & $\begin{array}{l}\text { Harvester } \\
\text { Don } 1500 \\
\end{array}$ & - \\
\hline 187 & Transfer of soybean seeds & $\begin{array}{l}\text { Kamaz grain carrier } \\
6360\end{array}$ & - \\
\hline 188 & Drip tape cleaning & MTZ-1221 & $\begin{array}{l}\text { GDM EzyLift } \\
\text { Plastic Mulch } \\
\text { Lifter }\end{array}$ \\
\hline 190 & $\begin{array}{l}\text { Preservation and dismantling of the drip irrigation system, } \\
\text { including the fertigation system (without cleaning from the } \\
\text { drip tape ridges) }\end{array}$ & \multicolumn{2}{|c|}{ Manually } \\
\hline 191 & $\begin{array}{l}\text { Removal of elements of the drip irrigation and fertigation } \\
\text { system }\end{array}$ & MTZ-1221 & 2 PTS-4 \\
\hline 192 & Peeling in two tracks to a depth of $0.06-0.08 \mathrm{~m}$ & MTZ-1221 & LDS-2,5 \\
\hline
\end{tabular}

\section{Results and its discussion}

As a result of approbation of the method of rice cultivation on checks of the rice irrigation system with drip irrigation under polyethylene and biodegradable mulching perforated film, it was possible to prove the effectiveness of not only rice cultivation (Table 2), but also rice crop rotation crops (Table 3 ). 
Table 2. Quantitative, qualitative and biological characteristics of the Rapan rice variety.

\begin{tabular}{|c|c|c|c|c|c|}
\hline № & \multirow{2}{*}{ Name } & \multicolumn{4}{|c|}{ Years } \\
\hline & & 2016 & 2017 & 2018 & 2019 \\
\hline 1 & Vegetation period & 117 & 119 & 118 & 120 \\
\hline 2 & Panicle height, $\mathrm{cm}$ & 90,4 & 90,8 & 91,4 & 91,2 \\
\hline 3 & Panicle length, $\mathrm{cm}$ & 17,6 & 18,3 & 18,8 & 18,9 \\
\hline 4 & The number of spikelets in a panicle, pcs. & 204 & 208 & 210 & 215 \\
\hline 5 & $\begin{array}{c}\text { Number of grains, pcs.: } \\
\text { - general } \\
\text { - empty }\end{array}$ & $\begin{array}{c}75 \\
2\end{array}$ & $\begin{array}{c}77 \\
2\end{array}$ & $\begin{array}{c}79 \\
1\end{array}$ & $\begin{array}{c}82 \\
1\end{array}$ \\
\hline 6 & Emptyness, \% & 2,6 & 2,2 & 1,8 & 1,5 \\
\hline 7 & Caryopsis length to width ratio $(1 / b)$ & 1,9 & 2,0 & 2,1 & 2,2 \\
\hline 8 & $\begin{array}{l}\text { Weight g/plant: } \\
\text { - grain } \\
\text { - straw } \\
\end{array}$ & $\begin{array}{l}2,5 \\
2,3\end{array}$ & $\begin{array}{l}2,6 \\
2,3\end{array}$ & $\begin{array}{l}2,6 \\
2,3\end{array}$ & $\begin{array}{l}2,6 \\
2,4\end{array}$ \\
\hline 9 & Straw to grain ratio & 0,92 & 0,88 & 0,88 & 0,92 \\
\hline 10 & Weight of 1000 grains, $g$ & 28 & 27 & 29 & 30 \\
\hline 11 & Productivity, t/ha & 11,3 & 11,6 & 12,1 & 13,4 \\
\hline 12 & Yield control, t/ha & 10,5 & 10,7 & 10,8 & 10,5 \\
\hline 13 & $\begin{array}{c}\text { Increase in yield } \\
-\mathrm{t} / \mathrm{ha} \\
-\% \\
\end{array}$ & $\begin{array}{l}0,8 \\
7,1\end{array}$ & $\begin{array}{l}0,9 \\
7,8\end{array}$ & $\begin{array}{c}1,3 \\
10,7\end{array}$ & $\begin{array}{c}2,9 \\
21,6\end{array}$ \\
\hline
\end{tabular}

Table 3. Characteristics of the accompanying crop - peas.

\begin{tabular}{|c|c|c|c|}
\hline \multicolumn{4}{|c|}{ Rice crop yield } \\
\hline $\begin{array}{c}\text { Tomato - variety } \\
\text { Riddle, } \mathrm{kg} / \mathrm{m}^{2}\end{array}$ & $\begin{array}{c}\text { Peas - variety } \\
\text { Prizer, c/ha }\end{array}$ & $\begin{array}{c}\text { Sweet pepper - variety Bison, } \\
\mathrm{kg} / \mathrm{m}^{2}\end{array}$ & $\begin{array}{c}\text { Lupine - variety Irbis, } \\
\mathrm{c} / \mathrm{ha}\end{array}$ \\
\hline 22 & 45,6 & 7,5 & 26,8 \\
\hline
\end{tabular}

The use of the claimed method of rice cultivation made it possible to improve the reclamation state of soils (Table 4).

Table 4. The dynamics of the reclamation state of soils in the experimental field in LLC "Chernoerkovskoe" of the Slavyansky district of the Krasnodar Territory, with an area of 4.5 hectares for 2016-2019 when cultivating rice on drip irrigation under mulching perforated film.

\begin{tabular}{|c|c|c|c|c|c|}
\hline $\begin{array}{c}\text { № } \\
\text { indicator }\end{array}$ & Name & $\begin{array}{c}\text { Indicator } \\
\text { unit }\end{array}$ & $\begin{array}{c}\text { Year } \\
\text { research }\end{array}$ & Indicator value & $\begin{array}{c}\text { Assessment of the } \\
\text { reclamation state of soils }\end{array}$ \\
\hline 1 & 2 & 3 & 4 & 5 & 6 \\
\hline \multirow{8}{*}{1} & \multirow{8}{*}{$\begin{array}{l}\text { Groundwater level / } \\
\text { Groundwater salinity }\end{array}$} & \multirow{8}{*}{$\mathrm{m} /(\mathrm{g} / \mathrm{l})$} & \multirow{2}{*}{2016} & 1,5 & \multirow{2}{*}{1} \\
\hline & & & & 2,98 & \\
\hline & & & \multirow{2}{*}{2017} & 1,6 & \multirow{2}{*}{1} \\
\hline & & & & 2,82 & \\
\hline & & & \multirow{2}{*}{2018} & 1,7 & \multirow{2}{*}{1} \\
\hline & & & & 2,64 & \\
\hline & & & \multirow{2}{*}{2019} & 1,8 & \multirow{2}{*}{1} \\
\hline & & & & 2,28 & \\
\hline \multirow{4}{*}{2} & \multirow{4}{*}{ Soil pH } & \multirow{4}{*}{ - } & 2016 & 6,7 & 1 \\
\hline & & & 2017 & 6,8 & 1 \\
\hline & & & 2018 & 7,0 & 1 \\
\hline & & & 2019 & 7,0 & 1 \\
\hline \multirow{4}{*}{3} & \multirow{4}{*}{ Humus content } & \multirow{4}{*}{$\%$} & 2016 & 3,9 & 4 \\
\hline & & & 2017 & 3,9 & 4 \\
\hline & & & 2018 & 4,0 & 3 \\
\hline & & & 2019 & 4,2 & 3 \\
\hline
\end{tabular}




\begin{tabular}{|c|c|c|c|c|c|}
\hline \multirow{4}{*}{4} & \multirow{4}{*}{$\begin{array}{l}\text { Humus reserves in the } \\
\text { layer } 0-100 \mathrm{~cm}\end{array}$} & \multirow{4}{*}{$\mathrm{t} / \mathrm{ha}$} & 2016 & 184 & 4 \\
\hline & & & 2017 & 189 & 4 \\
\hline & & & 2018 & 194 & 4 \\
\hline & & & 2019 & 202 & 3 \\
\hline \multirow{4}{*}{5} & \multirow{4}{*}{$\begin{array}{l}\text { Hydrolysable nitrogen } \\
\text { supply (according to } \\
\text { Tyunin - Kononova) }\end{array}$} & \multirow{4}{*}{$\mathrm{mg} / 100 \mathrm{~g}$} & 2016 & 4,9 & 4 \\
\hline & & & 2017 & 5,3 & 3 \\
\hline & & & 2018 & 5,4 & 3 \\
\hline & & & 2019 & 5,7 & 3 \\
\hline \multirow{4}{*}{6} & \multirow{4}{*}{$\begin{array}{l}\text { Availability of mobile } \\
\text { phosphorus (according } \\
\text { to Chirikov) }\end{array}$} & \multirow{4}{*}{$\mathrm{mg} / 100 \mathrm{~g}$} & 2016 & 4,2 & 4 \\
\hline & & & 2017 & 4,6 & 4 \\
\hline & & & 2018 & 5,0 & 4 \\
\hline & & & 2019 & 5,2 & 3 \\
\hline \multirow{4}{*}{7} & \multirow{4}{*}{$\begin{array}{c}\text { Availability of mobile } \\
\text { potassium (according to } \\
\text { Chirikov) }\end{array}$} & \multirow{4}{*}{$\mathrm{mg} / 100 \mathrm{~g}$} & 2016 & 3,5 & 4 \\
\hline & & & 2017 & 3,8 & 4 \\
\hline & & & 2018 & 4,1 & 3 \\
\hline & & & 2019 & 4,8 & 3 \\
\hline \multirow{4}{*}{8} & \multirow{4}{*}{$\begin{array}{l}\text { Enrichment with } \\
\text { nitrogen } \mathrm{C}: \mathrm{N}\end{array}$} & \multirow{4}{*}{ - } & 2016 & 11,2 & 4 \\
\hline & & & 2017 & 10,3 & 3 \\
\hline & & & 2018 & 9,7 & 3 \\
\hline & & & 2019 & 9,1 & 3 \\
\hline \multirow{4}{*}{9} & \multirow{4}{*}{$\begin{array}{l}\text { The content of } \\
\text { exchangeable } \\
\text { magnesium in the soil } \\
(\mathrm{MgO})\end{array}$} & \multirow{4}{*}{$\begin{array}{l}\mathrm{mg} / \mathrm{kg} \\
\text { of soil }\end{array}$} & 2016 & 57 & 4 \\
\hline & & & 2017 & 62 & 3 \\
\hline & & & 2018 & 68 & 3 \\
\hline & & & 2019 & 74 & 3 \\
\hline \multirow{4}{*}{10} & \multirow{4}{*}{$\begin{array}{c}\text { Sulphate (mobile) sulfur } \\
\text { content, } \mathrm{S}\end{array}$} & & 2016 & 9,4 & 4 \\
\hline & & & 2017 & 9,9 & 4 \\
\hline & & of soil & 2018 & 10,4 & 3 \\
\hline & & & 2019 & 10,8 & 3 \\
\hline & & & 2016 & 29 & 4 \\
\hline 11 & Saturation with haces $\mathrm{V}$ & 0 & 2017 & 32 & 4 \\
\hline 11 & Saturation will Uases, v & 70 & 2018 & 38 & 4 \\
\hline & & & 2019 & 46 & 3 \\
\hline & & & 2016 & 0,76 & 4 \\
\hline 12 & & & 2017 & 0,84 & 4 \\
\hline 12 & Structure factor, $K_{\text {str }}$ & - & 2018 & 0,91 & 4 \\
\hline & & & 2019 & 0,99 & 3 \\
\hline & & & 2016 & 40 & 5 \\
\hline & & & 2017 & 47 & 4 \\
\hline 13 & Total porosity & $\%$ & 2018 & 53 & 3 \\
\hline & & & 2019 & 61 & 2 \\
\hline & & & 2016 & 1,30 & 3 \\
\hline & Soil density (according & $\mathrm{cos}^{3}$ & 2017 & 1,26 & 2 \\
\hline 14 & to N.A.Kachinsky) & $\mathrm{g} / \mathrm{sm}^{3}$ & 2018 & 1,21 & 2 \\
\hline & & & 2019 & 1,17 & 1 \\
\hline & & & 2016 & 19,0 & 3 \\
\hline & & & 2017 & 24,0 & 3 \\
\hline 15 & $\begin{array}{l}\text { Soll nitrification } \\
\text { capacity }\end{array}$ & $\begin{array}{l}\mathrm{mg} \mathrm{NU_{3 } /} \\
\mathrm{kg}\end{array}$ & 2018 & 29,0 & 3 \\
\hline & & & 2019 & 34,0 & 2 \\
\hline & & & 2016 & 22 & 4 \\
\hline & Content of water- & & 2017 & 28 & 4 \\
\hline 16 & resistant aggregates in a & $\%$ & 2018 & 35 & 3 \\
\hline & layer of $0-30 \mathrm{~cm}$ & & 2019 & 41 & 2 \\
\hline
\end{tabular}




\begin{tabular}{|c|c|c|c|c|c|}
\hline & & & 2016 & 1,4 & 3 \\
\hline & & & & & \\
\hline & & & & 1,3 & 3 \\
\hline & Salt content & & 2017 & & \\
\hline 17 & / Salinity type & $\% /-$ & 2018 & 1,1 & 3 \\
\hline & & & 2018 & & \\
\hline & & & 2010 & 0,8 & 2 \\
\hline & & & 2019 & & \\
\hline & The "cumulative effect" & & 2016 & 1,94 & 3 \\
\hline & of toxic $\mathrm{CO}_{3}^{2-}, \mathrm{HCO}_{3}^{-}$ & & 2017 & 1,76 & 3 \\
\hline 18 & $\mathrm{Cl}^{-}, \mathrm{SO}_{4}^{2-}$ & $\mathrm{mg} \mathrm{Cl}^{-}$ & 2018 & 1,43 & 3 \\
\hline & $\begin{array}{l}\text { (N. I. Bazilevich, } \\
\text { E. I. Pankova) }\end{array}$ & & 2019 & 1,08 & 2 \\
\hline & & & 2016 & 9,8 & 4 \\
\hline & & & 2017 & 11,4 & 3 \\
\hline 19 & Issue rate of $\mathrm{CO}_{2}$ in soil & $\mathrm{CO}_{2} /(10$ & 2018 & 13,9 & 3 \\
\hline & & & 2019 & 15,6 & 2 \\
\hline & & Tra & e eleme & tent: & \\
\hline & & & 2016 & 19 & 0,8 \\
\hline & Manganese (Mn) & & 2017 & 21 & 0,6 \\
\hline & (in $0,1 \mathrm{n} . \mathrm{H}_{2} \mathrm{O}_{4}$ ) & & 2018 & 24 & 0,6 \\
\hline & & & 2019 & 26 & 0,6 \\
\hline & & & 2016 & 1,80 & 0,6 \\
\hline & Cuprum $(\mathrm{Cu})$ & & 2017 & 2,10 & 0,6 \\
\hline & (in $0,1 \mathrm{n} . \mathrm{KCl}$ ) & & 2018 & 2,40 & 0,6 \\
\hline & & & 2019 & 2,50 & 0,6 \\
\hline & & & 2016 & 0,40 & 0,8 \\
\hline 20 & Zinc (Zn) & $\mathrm{mg} / \mathrm{kg}$ & 2017 & 0,60 & 0,8 \\
\hline & (in $0,1 \mathrm{n} . \mathrm{KCl}$ ) & of soil & 2018 & 0,80 & 0,8 \\
\hline & & & 2019 & 1,10 & 0,6 \\
\hline & & & 2016 & 1,10 & 0,8 \\
\hline & Cobalt (Co) & & 2017 & 1,40 & 0,8 \\
\hline & (in $0,1 \mathrm{n} . \mathrm{HNO}_{3}$ ) & & 2018 & 1,80 & 0,6 \\
\hline & & & 2019 & 2,10 & 0,6 \\
\hline & & & 2016 & 0,18 & 0,8 \\
\hline & Molybdenum (Mo) & & 2017 & 0,21 & 0,6 \\
\hline & (in the extract of & & 2018 & 0,25 & 0,6 \\
\hline & & & 2019 & 0,28 & 0,6 \\
\hline & & & 2016 & & \\
\hline & & & 2016 & & \\
\hline & of the noints of the indic & & 2017 & & \\
\hline $\begin{array}{l}\text { Ihe s } \\
\text { reclam }\end{array}$ & $\begin{array}{l}\text { of the points of the indica } \\
\text { on state of the soil / Assess }\end{array}$ & $\begin{array}{l}\text { ors of the } \\
\text { ment of the }\end{array}$ & 2017 & & \\
\hline & $\begin{array}{l}\text { n state of the soil / Assess } \\
\text { reclamation state of the so }\end{array}$ & ment of the & 2018 & & \\
\hline & & & 2018 & & \\
\hline & & & 2019 & & \\
\hline & & & 2019 & & \\
\hline
\end{tabular}

\section{Output}

The efficiency of the developed technology of cultivation of rice on drip irrigation under polyethylene and mulching perforated film on the lands of the irrigation fund has been proved. 
The main performance indicators are:

- reduction of the irrigation rate by 5.3 times relative to the traditional technology of rice cultivation by flooding;

- improvement of the reclamation state of soils;

- reduction of labor intensity on average by $34 \%$;

- increasing the yield by an average of $20 \%$ and the quality of the resulting grain;

- reducing the cost of rice production on average by $15 \%$;

- decrease in the amount of introduced macro and microelements on average by $30 \%$;

- increasing profitability by $22 \%$.

\section{References}

1. Z.Chen, P.Li, S. Jiang, et al., Science of The Total Environment, 757, 143748 (2021)

2. H. Chen, W. Zeng, Y. Jin, et al., Journal of Hydrology, 591, 125325(2020)

3. M. D. M. Kadiyala, J. W. Jones, R. S. Mylavarapu. Y. C. Li, M. D. Reddy,

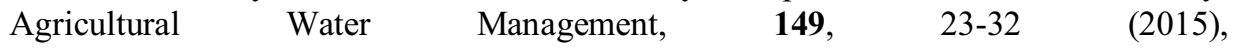
doi.org/10.1016/j.agwat.2014.10.019

4. S. M. P. Banik, Journal of Environmental Management, 279, 111620 (2021), doi.org/10.1016/j.jenvman.2020.111620

5. M. Ishfaq, N. Akbar, S. A. Anjum, M. Anwar-Ijl-Haq, Journal of Integrative Agriculture 19(11), 2656-2673 (2020)

6. S. F. Islam, B. O. Sander, J. R. Quilty, et al., Science of The Total Environment, 739, 140215 (2020), doi.org/10.1016/j.scitotenv.2020.140215

7. S. S. Girsang, T. Q. Correa Jr, J. R. Quilty, et al., Soil and Tillage Research, 202, 104647 (2020), doi.org/10.1016/j.still.2020.104647

8. R. Joshia, B. Singh, A. Shukla, Current Plant Biology, 13, 45-52 (2018), doi.org/10.1016/j.cpb.2018.05.001

9. M. A. B. Pinto, J. M. B. Parfitt, L. C. Timm, et al., Field Crops Research, 248, 107714 (2020), doi.org/10.1016/j.fcr.2020.107714

10. F. Monaco, G. Sali, Agricultural Water Management, 195, 47-57 (2018)

11. T. Safronova, S. Vladimirov, I. Prikhodko, and A. Sergeyev, E3S Web of Conferences 210, ITSE-2020 05014 (2020), doi.org/10.1051/e3sconf/202021005014

12. S. Vladimirov, T. Safronova, and I. Prikhodko, IOP Conf. Series: Materials Science and Engineering 913, 042008 (2020), doi:10.1088/1757-899X/913/4/042008

13. S. Vladimirov, T. Safronova, and I. Prikhodko, International Agricultural Journal, 62 (4) 171-185 (2019), doi:10.24411/2588-0209-2019-10093

14. D. P. Patel, A. Dasb, G. C. Munda, et al., Agricultural Water Management, 97(9), 1269-1276 (2010), doi.org/10.1016/j.agwat.2010.02.018

15. A. López-Piñeiro, D. Peña, Á.l Albarrán, et al., Journal of Environmental Management, 237, 44-53 (2019), doi.org/10.1016/j.jenvman.2019.02.058

16. I. P. Kruzhilin, M. A. Ganiev, V. V. Melikhov, et al., Water saving eco-friendly technology of rice irrigation, In Proceedings of the conference AgroCON-2019, 012100 (2019)

17. I. P. Kruzhilin, S. D. Fomin, T. A. Gamm, A. A. Mushinskiy, Assessing the ecological state of agricultural irrigated fields of the orenburg gas processing complex with dumping sewage water for crop irrigation, in Proceedings of 2019th International 
Symposium on Earth Sciences: History, Contemporary Issues and Prospects, 012037 (2019)

18. I. P. Kruzhilin, A. S. Ovchinnikov, N. V. Kuznetsova, et al., ARPN Journal of Engineering and Applied Sciences, 13(13), 4181-4184 (2018)

19. I. P. Kruzhilin, M. A. Ganiev, V. V. Melikhov, et al., ARPN Journal of Engineering and Applied Sciences, 12(24), 7118-7123 (2017)

20. P. Vijayaraghavareddy, Y. Xinyou, P. C. Struik, et al., Rice Science, 27(4), 345-354 (2020) doi.org/10.1016/j.rsci.2020.05.009

21. G. Arbat, S. Cufí, M. Duran-Ros, et al., Water (Switzerland), 12(6), 1724 (2020) 